\title{
Ceramic Toughening Strategies for Biomedical Applications
}

\author{
Rushui Bai ${ }^{1,2 \dagger}$, Qiannan Sun ${ }^{1,2 \dagger}$, Ying He ${ }^{2,3 \dagger}$, Liying Peng ${ }^{1,2}$, Yunfan Zhang ${ }^{1,2}$, \\ Lingyun Zhang ${ }^{1,2}$, Wenhsuan Lu ${ }^{1,2}$, Jingjing Deng ${ }^{2,3}$, Zimeng Zhuang ${ }^{1,2}$, Tingting $\mathrm{Yu}^{1,2 *}$ and \\ Yan $W_{e i}{ }^{2,3 *}$ \\ ${ }^{1}$ Department of Orthodontics, Peking University School and Hospital of Stomatology, Beijing, China, ${ }^{2}$ National Engineering \\ Laboratory for Digital and Material Technology of Stomatology and Beijing Key Laboratory of Digital Stomatology, Beijing, China, \\ ${ }^{3}$ Department of Geriatric Dentistry, Peking University School and Hospital of Stomatology, Beijing, China
}

OPEN ACCESS

Edited by:

Yanyu Yang,

Zhengzhou University, China

Reviewed by:

Dan Wang,

Beijing University of Chemical

Technology, China

Dongpeng Yan,

Beijing Normal University, China

Ahmed El-Fiqi,

Dankook University, South Korea

Liu Weipeng,

Hebei University of Technology, China

*Correspondence:

Tingting $Y u$

tingtingyu@bjmu.edu.cn

Yan Wei

kqweiyan@bjmu.edu.cn

${ }^{\dagger}$ These authors have contributed equally to this work

Specialty section:

This article was submitted to Biomaterials,

a section of the journal

Frontiers in Bioengineering and

Biotechnology

Received: 21 December 2021 Accepted: 09 February 2022

Published: 07 March 2022

Citation:

Bai R, Sun Q, He Y, Peng L, Zhang Y, Zhang L, LuW, Deng J, Zhuang Z, YUT and Wei $Y$ (2022) Ceramic Toughening Strategies for Biomedical Applications. Front. Bioeng. Biotechnol. 10:840372. doi: 10.3389/fbioe.2022.840372
Aiming at shortage of metal materials, ceramic is increasingly applied in biomedicine due to its high strength, pleasing esthetics and good biocompatibility, especially for dental restorations and implants, artificial joints, as well as synthetic bone substitutes. However, the inherent brittleness of ceramic could lead to serious complications, such as fracture and disfunction of biomedical devices, which impede their clinical applications. Herein, several toughening strategies have been summarized in this review, including reinforcing phase addition, surface modification, and manufacturing processes improvement. Doping metal and/or non-metal reinforcing fillers modifies toughness of bulk ceramic, while surface modifications, mainly coating, chemical and thermal methods, regulate toughness on the surface layer. During fabrication, optimization should be practiced in powder preparation, green forming and densification processes. Various toughening strategies utilize mechanisms involving fine-grained, stress-induced phase transformation, and microcrack toughening, as well as crack deflection, bifurcation, bridging and pull-out. This review hopes to shed light on systematic combination of different toughening strategies and mechanisms to drive progress in biomedical devices.

Keywords: ceramic, biomedical, fracture, toughening, reinforcing phase, surface modification, manufacture, toughening mechanism

\section{INTRODUCTION}

With the aging of the population, the demand for maintaining the quality of life is in needed worldwide. The tooth loss (Zitzmann et al., 2007), symptomatic osteoarthritis (Pivec et al., 2012; Hunter and Bierma-Zeinstra, 2019), as well as bone defects and dysfunction (Carrington, 2005; Olshansky et al., 2005) have become global health care problems, which lead to growing markets for high-quality biomedical devices (Zitzmann et al., 2007; Kim et al., 2008; Chevalier and Gremillard, 2009; Carr et al., 2012; Patel et al., 2015). Large amount of these devices are made of metal but their metal-color (Bayne et al., 2019), high wear rates of bearing components and large amount of ion release (Chevalier and Gremillard, 2009) greatly impede their clinical applications. Thus, benefited from its excellent mechanical, esthetic (Bayne et al., 2019) and biocompatible properties (Gao et al., 2014; Ruiz Henao et al., 2021), ceramic becomes potential candidate for biomedical applications, such as dental restorations (Li et al., 2014; Spitznagel et al., 2018), dental implants (Kohal et al., 2008; Saadaldin and Rizkalla, 2014), heads and cups of joint replacements (Rahaman et al., 2007), as well as bone fillers and scaffolds (Ma et al., 2018) for tissue engineering. Although ceramic materials show their huge potential and preponderance, high brittleness of ceramic restrains its biomedical 
applications, which might result in severe clinical complications, such as fracture (Benaqqa et al., 2005; Koo et al., 2014; Morimoto et al., 2016; Kong et al., 2019). Failures of ceramic mostly happen in the absence of extrinsic shielding mechanisms, where fracture invariably occurs catastrophically by cohesive bond breaking at the crack tip with a resulting very low intrinsic toughness of roughly 1-3 $\mathrm{MPa} \mathrm{m}^{1 / 2}$ (Launey and Ritchie, 2009). Therefore, the extreme brittleness of ceramic materials highlights the importance of ceramic toughening.

Toughness of materials could be thought as the ability to dissipate deformation energy without crack propagation (Launey and Ritchie, 2009). One of the widely recognized methods of computing toughness, denoted here as $\tau$, is by the area under the engineering stress $\sigma$ vs. engineering strain $\varepsilon$ curve determined in a tensile test (Sehaqui et al., 2013). Thus

$$
\tau=\int_{0}^{\varepsilon_{b}} \sigma d \varepsilon
$$

Where $\varepsilon_{\mathrm{b}}$ is the elongation at break. The term "toughness" is also used to the critical outcome of impact testing, namely the energy required to generate fracture at high rates of force application (Bai et al., 2012). Thus, there is fracture toughness, notch toughness, determined in impact testing for a predetermined geometry of the notch and testing methods, or else drop impact toughness (Brostow et al., 2015). Fracture toughness is the focus of this review, and a variety of testing methods have been proposed, such as indentation fracture (IF) (Evans and Charles, 1976; Lawn et al., 1980; Anstis et al., 1981), single-edge notched beam (SENB) (Damani et al., 1996), single-edge precracked beam (SEPB) (Cesar et al., 2005), single-edge V-notched beam (SEVNB), chevron notch $(\mathrm{CN})$, surface crack in flexure (SCF) and double cantilever beam (DCB) methods (Wang et al., 2017).

Crack growth is promoted ahead of the crack tip by intrinsic microstructural damage, and impeded by extrinsic mechanisms acting primarily behind the crack tip, which serve to "shield" the crack tip from the far-field driving forces (Ritchie, 1988). Toughness can be enhanced by increasing the microstructural resistance, such as by changing the nature and distribution to suppress damage in the form of microcracking or microvoid formation ahead of the crack tip, which is termed intrinsic toughening. However, this approach is largely ineffective with brittle materials such as ceramic (Evans, 1990), which invariably must rely on extrinsic toughening. Extrinsic toughening involves microstructural mechanisms that act primarily behind the crack tip to effectively reduce the crack-driving force actually experienced at the crack tip; this is termed crack-tip shielding and can occur by such mechanisms as in situ phase transformations and crack bridging (Launey and Ritchie, 2009). Brittle materials, such as ceramics, are invariably toughened with extrinsic mechanisms (Evans, 1990; Becher, 1991), which depend on crack size and to some degree specimen geometry. A principle manifestation of this cracksize dependent fracture behavior is resistance-curve (R-curve) toughness behavior where the crack driving force to sustain cracking increases with crack extension. Extrinsic toughening mechanisms mainly affect the crack growth, while have little effect on crack initiation.
Biomedical used-ceramic is applied as structural material, where catastrophic fracture is strictly prohibited and might lead to medical malpractice. Therefore, systematic investigation on ceramic toughness and recent progress of its modulation strategies are vastly required. However, there is limited number of reviews concerning ceramic toughening strategies, especially for biomedical applications (Naslain, 2004; Asl et al., 2018; Siddiqui et al., 2018). Therefore, this review provides an overview of crack-tip shielding methods to realize extrinsic toughening for biomedical ceramic (Figure 1), from adding reinforcing second phase (summarized in Table 1), surface modification to manufacturing optimization. And toughening mechanisms are also introduced briefly to deepen understanding of these strategies.

\section{ADDING REINFORCING FILLER AS SECOND PHASE TO CERAMIC MATRIX}

Concept of ductile-phase toughening is to introduce metal component, non-metal component or ductile polymers into a brittle matrix, like ceramic, to increase its toughness. The development of metal-toughened ceramic mainly associates with alumina $\left(\mathrm{Al}_{2} \mathrm{O}_{3}\right)$ and zirconia $\left(\mathrm{ZrO}_{2}\right)$, which could act as either matrix or reinforcement. And a large family of non-metal components used to toughen ceramic are nanocarbon materials, from one-dimensional to three-dimensional. Additionally, polymers infiltrated ceramics gain lots of attention recently. Apart from adding every type of fillers alone, combined materials of several types could also achieve the toughening purpose (Figure 2).

\subsection{Metal Oxide and Metal Reinforcements}

In 1976, $\mathrm{ZrO}_{2}$ was revealed to display high toughness (R. C. Garvie and Hannink, 1975), which ushered in a decade of exceptional ceramic toughening development, culminating in materials having toughness on the order of $20 \mathrm{MPa} \mathrm{m} \mathrm{m}^{1 / 2}$ (Evans, 1990). Undoped $\mathrm{ZrO}_{2}$ displays three phases at different temperature: the monoclinic $(\mathrm{m})$ phase of undoped $\mathrm{ZrO}_{2}$ is thermodynamically stable at temperatures below $1,170^{\circ} \mathrm{C}$; it is a tetragonal $(\mathrm{t})$ phase from 1,170 to $2,370^{\circ} \mathrm{C}$, and a cubic (c) phase above $2,370^{\circ} \mathrm{C}$ until the melt occurs at $2,706^{\circ} \mathrm{C}$ (French et al., 1994). Because the t-to-m phase transformation in zirconia may be used to toughen the material and enhance its mechanical properties, it has sparked a lot of technological interest in zirconia and composites incorporating zirconia (Heuer, 1987).

Using $\mathrm{ZrO}_{2}$ alone have the shortage of low-temperature degradation (LTD) (Kohorst et al., 2012), so $\mathrm{Al}_{2} \mathrm{O}_{3}$ are doped to exert synergistic effect. Two composite materials can be made in the $\mathrm{ZrO}_{2}-\mathrm{Al}_{2} \mathrm{O}_{3}$ system as follows: $\mathrm{Al}_{2} \mathrm{O}_{3}$ reinforced with $\mathrm{ZrO}_{2}$ particles and denominated as zirconia toughened alumina (ZTA), or $\mathrm{ZrO}_{2}$ reinforced with $\mathrm{Al}_{2} \mathrm{O}_{3}$ particles, named alumina toughened zirconia (ATZ) (Nevarez-Rascon et al., 2009). According to the findings of De Aza et al. (Ritchie, 1988; De Aza et al., 2002) and Gregori et al. (Gregori et al., 1999), the fracture toughness of the ceramic matrix material 


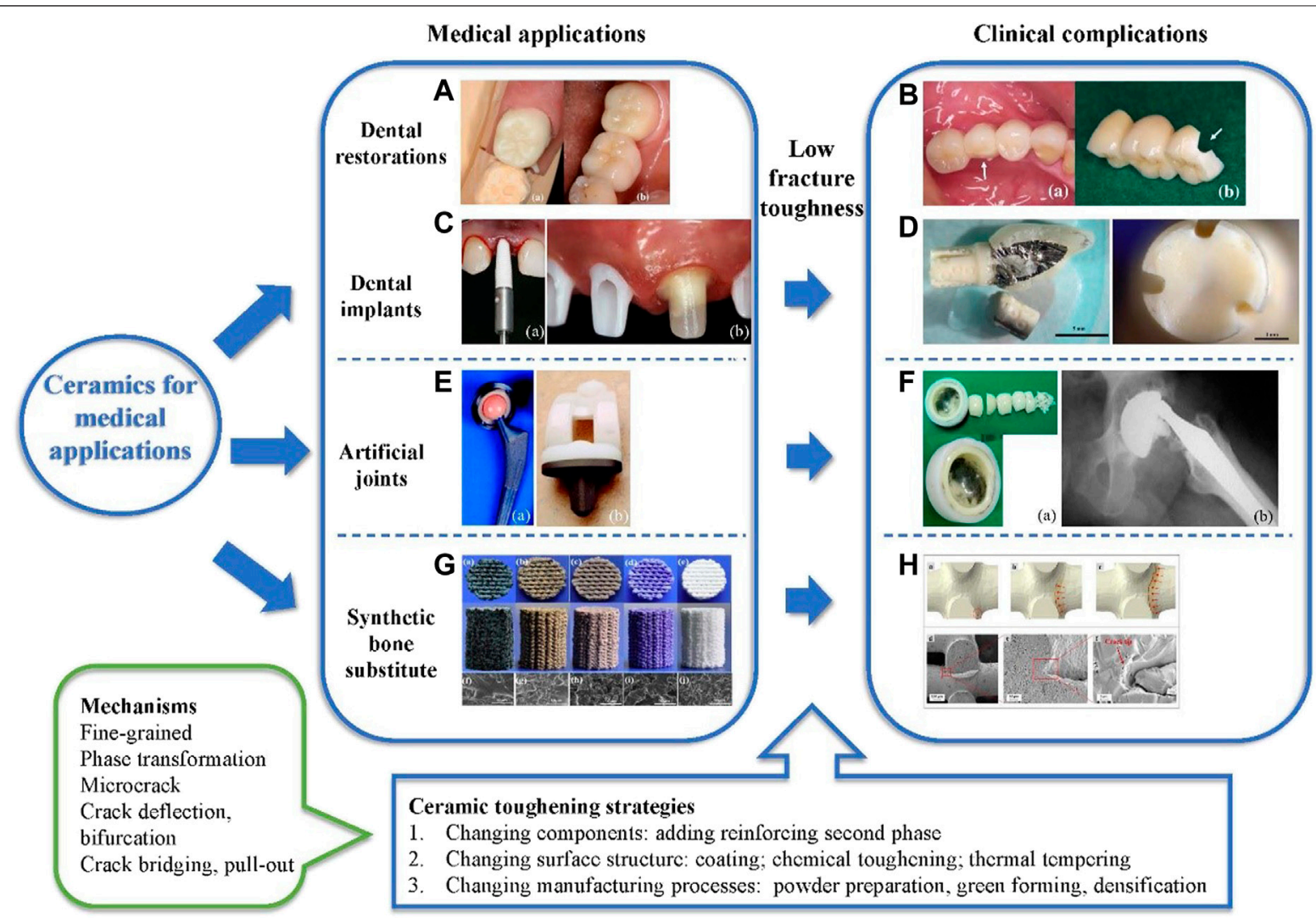

FIGURE 1 | Medical applications of ceramics, corresponding clinical complications due to the low fracture toughness of ceramics, as well as toughening strategies and underlying mechanisms. (A) Fully contoured zirconia crown, (a) before polishing and (b) from the occlusal view (second lower left molar) (Miyazaki et al., 2013). (B), (a) Chipping of the ceramic veneer; (b) Framework fracture in the second upper left molar distal buccal (Miyazaki et al., 2013). (C), (a) Insertion of the ceramic implant; (b) Ceramic abutments (zirconia) attached to the implants intraorally (Kohal et al., 2008). (D) Extracted fractured implant and crown, as well as fractured surface (Kong et al., 2019). (E), (a) Prosthetic hip implants with ceramic-on-ceramic $\left(\mathrm{Al}_{2} \mathrm{O}_{3}-\mathrm{on}-\mathrm{Al}_{2} \mathrm{O}_{3}\right)$ bearing couple; (b) Prosthetic knee implants with ceramic-on-UHMWPE bearing couple (Rahaman et al., 2007). (F), (a) Five large pieces of a fractured ceramic head and many small fragments; (b) Radiograph showing the fracture of the ceramic femoral head (Toran et al., 2006; Hwang et al., 2007). (G) Photograph of 3D-printed bioactive glass-ceramic scaffolds (Liu et al., 2018). (H) Crack initiation and propagation path shown by (a-c) XFEM analysis and (d-f) FE-SEM images (Entezari et al., 2016). UHMWPE, ultra-high-molecular-weight polyethylene; XFEM, extended finite element method; FE-SEM, field emission scanning electron microscopy.

rose in both cases. ZTA can be considered a new generation of toughened ceramic, with toughness exceeding $12 \mathrm{MPa} \mathrm{m} \mathrm{m}^{1 / 2}$, compared to $3 \mathrm{MPa} \mathrm{m}{ }^{1 / 2}$ for commercial alumina ceramic. The inclusion of discrete zirconia grains in the alumina matrix as a second phase allows the former to behave intrinsically, that is, to undergo the t-to-m transformation or to remain in the metastable tetragonal state after cooling of the composites from fabrication temperatures (Wang and Stevens, 1989). ZTA is microstructurally separated into four classes by Wang et al. (Figure 2A) (Wang and Stevens, 1989): (I) alumina with dispersed unstabilized zirconia (Figures 2A,a); (II) alumina with dispersed partially stabilized zirconia (PSZ) (Figures 2A,b); (III) alumina with PSZ agglomerates (Figures 2A,c); (IV) alumina-zirconia duplex structures (Figures 2A,d).

Except for these basic forms of $\mathrm{ZrO}_{2}-\mathrm{Al}_{2} \mathrm{O}_{3}$ materials, the shapes of both components could be altered, or other metal compounds could be added, to achieve better toughening effect. Aguilar-Elguézabal and Bocanegra-Bernal (2013) investigated the fracture toughness of an $\mathrm{Al}_{2} \mathrm{O}_{3}(\mathrm{n})-70 \mathrm{wt} \% \mathrm{ZrO}_{2}\left(\mathrm{ZrO}_{2}\right.$ with $3 \mathrm{~mol}$
\% yttria, TZ-3Y)n nanocomposite with addition of $2.5 \% \mathrm{Al}_{2} \mathrm{O}_{3}$ whiskers. The fracture toughness was enhanced 62,28 , and $7 \%$ over pure $\mathrm{Al}_{2} \mathrm{O}_{3}$, the composite without additions of whiskers, and pure TZ-3Y for medical applications, respectively. They achieved a maximum fracture toughness of $6.9 \mathrm{MPa} \mathrm{m}^{1 / 2}$ with an average grain size of $0.4 \pm 0.17 \mu \mathrm{m}$, and found microcracking, crack deflection and phase transformation toughening mechanisms could contribute to the improvement of fracture toughness. Additionally, the $\mathrm{Al}_{2} \mathrm{O}_{3}$ whiskers did not affect other intrinsic properties during the toughening process. Santos et al. (2021) not only added $\mathrm{Al}_{2} \mathrm{O}_{3}$ in $\mathrm{ZrO}_{2}$, but also replaced the conventional tetragonal zirconia stabilized with $3 \mathrm{~mol} \%$ yttria (3Y-TZP) with ceria and yttria stabilized zirconia, namely (Ce, Y)-TZP. And this new composite received higher fracture toughness, elastic modulus and hardness than those obtained for 3Y-TZP. In the meantime, its values of Weibull modulus ( $\mathrm{m}>$ 10 ) and flexural strength (>950 MPa) were similar to the $3 \mathrm{Y}-\mathrm{TZP}$ ceramics, with high resistance to degradation in saliva, indicating adequate properties for dental application. They thought several 
TABLE 1 | Summary of adding reinforcing second phase in bioceramics.

Classification Second phase Volume fraction Ceramic matrix

$K_{10}$

\section{$\mathrm{K}_{\mathrm{lc}}$ testing}

Maximum $\mathrm{K}_{\mathrm{t}}$ Maximum $K_{1 c}$
$\left(\mathrm{MPa} \cdot \mathrm{m}^{1 / 2}\right)$

Metal Oxide $\quad \mathrm{Al}_{2} \mathrm{O}_{3}$ whiskers $\quad 2.5 \mathrm{wt} \% \quad \mathrm{Al}_{2} \mathrm{O}_{3} / 3 \mathrm{Y}$-TZP Conventional sintering

and Metal

$$
\mathrm{Al}_{2} \mathrm{O}_{3} \text { platelets }
$$

$25 w t \%$

$$
(\mathrm{Ce}, \mathrm{Y})-\mathrm{TZP}
$$

Sintered at

$$
\begin{aligned}
& \text { Sintered at } \\
& 1,500^{\circ} \mathrm{C}, 2 \mathrm{~h}
\end{aligned}
$$

IF

6.9

$\mathrm{Al}_{2} \mathrm{O}_{3}+\mathrm{SA} 6$

$\mathrm{Al}_{2} \mathrm{O}_{3}: 0,5,10,15 \quad$ 1Y6Ce-TZP

vol\%;

SA6: 15, 10, 5, 0

3Y-TZP

Nanocrystalline

vol\%

$0,5,10,15$,

$20 \mathrm{wt} \%$

Mica glass

ceramic

$\mathrm{CaSiO}_{3} / \mathrm{ZrO}_{2}$

Micrometer

mole ratio of 80 / sized $\beta-\mathrm{CaSiO}_{3}$

20 (C8Z2), 60/40

(C6Z4), 40/60

(C4Z6)

Needle-like ZnOw

1, 3, 5, 10 wt\%

Porous $\mathrm{CaSO}_{4} / \quad \mathrm{SLS}$

bioglass

$a-\mathrm{Al}_{2} \mathrm{O}_{3} \quad 5,10,15,25, \quad \begin{aligned} & \text { scaffolds } \\ & \alpha-\mathrm{CaSiO}_{3}\end{aligned}$

$50 \mathrm{wt} \%$

$\mathrm{Cs}_{2} \mathrm{O}$-stabilized $\quad 0.0-2.0 \mathrm{~mol} \%$

leucite core

particles

Commercial

porcelain (VP);

synthesized

leucite-based

AgNPs, PtNPs

500 ppm

porcelain (NP)

NS

Fired (vacuum:

$\left.730 \mathrm{mmHg}, 930^{\circ} \mathrm{C}\right)$

Sintered at $1,150^{\circ} \mathrm{C}$

and $1,250^{\circ} \mathrm{C}, 5 \mathrm{~h}$

Vacuum fired $\left(1,100^{\circ} \mathrm{C}, \quad\right.$

$20 \mathrm{~min}$

wo-stage heat

reatment sequence

S

(a)

$730 \mathrm{mmHg}, 930^{\circ} \mathrm{C}$ )

100, 200, 500,
$1,000 \mathrm{ppm}$
(Ag100, Ag200,
Ag500, Ag1000)

NS

Non-metal CNT

$4 \mathrm{wt} \%$

HA

HA

0.81 vol\%

ZTA

GPL

ZTA

SPS IF

F

$6.9 \pm 0.8$

$11.3 \pm 0.4$

0.8

SENB

12.5

(1)

$\begin{array}{ll}3.6 \pm 0.2 & 0.8 \pm 0.2 \text { (mica } \\ & \text { glass ceramic) } \\ 4.08 \pm 0.13 & 1.54 \pm 0.04(\beta- \\ (\mathrm{C} 6 \mathrm{Z} 4) & \left.\mathrm{CaSiO}_{3}\right)\end{array}$

Not mentioned

$4.2 \pm 0.4$ (Pure

$\left.\mathrm{Al}_{2} \mathrm{O}_{3(\mathrm{n})}\right)$

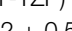

(3Y-TZP)

$1.67 \pm 0.04 \quad$ Not mentioned

$0.9 \pm 0.1$

$1.42 \pm$

0.21 (VP)

$2.15 \pm$

0.33 (NP)

$1.42 \pm 0.02$

(Pt-NS)

$1.54 \pm 0.05$

(Ag-NS)

$1.54 \pm 0.05$

(Ag500)

$1.51 \pm 0.08$

(Ag1000)

$2.40 \pm 0.60$

SENB

a- $\mathrm{CaSiO}_{3}$

$1.51 \pm 0.15(N P)$

$1.36 \pm 0.03$
$2.40 \pm 0.60$

$9.05 \pm 0.55$

(GPL/ZTA,

$\left.1,550^{\circ} \mathrm{C}\right)$
Mentioned toughening

mechanisms

Microcracking, crack Aguilar-Elguézabal

deflection, phase and

transformation toughening Bocanegra-Bernal,

(2013)

Phase transformation Santos et al. (2021)

toughening,

microcracking,

denomination coupled

toughening, crack

deflection, bridging and

pull-out

Phase transformation

toughening, crack

Gommeringer et al.

deflection, crack bridging,

microcracking

Phase transformation

toughening

Few $\beta$-CaSiO

into $a-\mathrm{CaSiO}_{3}$; the $\mathrm{ZrO}_{2}$

phase showed a network

structure in the matrix

Whisker pull-out, crack bridging, crack deflection, crack branching

$0.6 \pm 0.12$ (Pure Forming new phase

$\mathrm{CaAl}_{2} \mathrm{O}_{4}$ from reaction of

$\mathrm{CaSiO}_{3}$ and $\mathrm{Al}_{2} \mathrm{O}_{3}$

$0.85 \pm 0.11$ (VP) Phase transformation

toughening

2019)

Gali et al. (2018)

Long et al. (2008)

Greater elasticity of the metal than the matrix glass;

generation of hydrostatic

stress

$1.36 \pm 0.03 \quad$ Crack deflection, crack Uno et al. (2013) bridging

Shuai et al. (2016)

Shirazi et al. (2014)

Rasmussen et al.

(2004)

Fujieda et al. (2012)

$1.25 \pm 0.91(\mathrm{HA}) \quad \mathrm{In}$

interfacial shear strength and pull-out energy of CNT

from the HA matrix

$6.46 \pm 0.65$ (Pure Pull out, crack bridging, Liu et al. (2012)

ZTA, $1,550^{\circ} \mathrm{C}$ )

crack deflection 
TABLE 1 | (Continued) Summary of adding reinforcing second phase in bioceramics.

\begin{tabular}{|c|c|c|c|c|c|c|c|c|c|}
\hline Classification & $\begin{array}{l}\text { Second phase } \\
\text { fillers }\end{array}$ & $\begin{array}{l}\text { Volume fraction } \\
\text { of fillers }\end{array}$ & Ceramic matrix & $\begin{array}{l}\text { Fabrication } \\
\text { techniques }\end{array}$ & $\begin{array}{l}\mathrm{K}_{\mathrm{Ic}} \text { testing } \\
\text { method }\end{array}$ & $\underset{\left(\mathrm{MPa} \cdot \mathrm{m}^{1 / 2}\right)}{\operatorname{Maximum} \mathrm{K}_{\mathrm{lc}}}$ & $\mathrm{K}_{\mathrm{Ic}}$ of control & $\begin{array}{l}\text { Mentioned toughening } \\
\text { mechanisms }\end{array}$ & Ref. \\
\hline & GNP & $\begin{array}{l}0.5,1.0,1.5 \\
2.0 \mathrm{wt} \%\end{array}$ & $\mathrm{CaSiO}_{3}$ & HIP & $\begin{array}{l}\text { Nanoindentation } \\
\text { experiments }\end{array}$ & $\begin{array}{l}1.77 \pm 0.05 \\
(1 \mathrm{wt} \% \text { GNP) }\end{array}$ & $\begin{array}{l}0.76 \pm 0.18 \\
\left(\mathrm{CaSiO}_{3}\right)\end{array}$ & $\begin{array}{l}\text { Crack bridging, pull-out, } \\
\text { branching and deflection }\end{array}$ & Mehrali et al. (2014) \\
\hline & $\mathrm{GO}$ & $0-0.2 w t \%$ & 3Y-TZP & Hot-press sintering & IF & $\begin{array}{l}8.95 \pm 0.59 \\
(0.1 \mathrm{wt} \% \mathrm{GO})\end{array}$ & $40.9 \%$ lower & $\begin{array}{l}\text { Crack deflection, crack } \\
\text { bridging, GO put-out }\end{array}$ & Zhang et al. (2020) \\
\hline \multirow[t]{2}{*}{ Polymer } & PVA fibers & $2.5-5 w t \%$ & CPCs & $\begin{array}{l}\text { Set at room } \\
\text { temperature }(24 \mathrm{~h}) \text {, } \\
\text { immersed in PBS and } \\
\text { placed on a shaker } \\
\text { table set to } 120 \mathrm{rpm} \text { in } \\
\text { an incubator } \\
\left(37^{\circ} \mathrm{C}, 72 \mathrm{~h}\right)\end{array}$ & $\begin{array}{l}\text { Three-point } \\
\text { flexural test }\end{array}$ & $\begin{array}{l}\text { WOF: } 8.7 \pm \\
2.5 \mathrm{KJ} \mathrm{m}^{-2} \\
(5 \mathrm{wt} \% \mathrm{PVA} \\
\text { fibers })\end{array}$ & $\begin{array}{l}\text { WOF: } 0.020 \pm \\
0.008 \mathrm{KJ} \mathrm{m}^{-2} \\
\text { (fiber free CPCs) }\end{array}$ & $\begin{array}{l}\text { Fiber bridging, crack } \\
\text { deflection, frictional sliding }\end{array}$ & Kucko et al. (2019) \\
\hline & $\begin{array}{l}\text { PNIPAM- } \\
\text { functionalized PVA } \\
\text { fibers }\end{array}$ & $2.5 w t \%$ & CPCs & $\begin{array}{l}\text { Set at room } \\
\text { temperature }(12 \mathrm{~h}) \text {, } \\
\text { then immersed in PBS } \\
\left(37^{\circ} \mathrm{C}, 3 \text { days }\right)\end{array}$ & $\begin{array}{l}\text { Three-point } \\
\text { flexural tests }\end{array}$ & $\begin{array}{l}\text { WOF> } \\
1500 \mathrm{~J} \mathrm{~m}^{-2} \\
\text { (PVA) }\end{array}$ & $\begin{array}{l}\text { WOF }<100 \mathrm{~J} \cdot \mathrm{m}^{-2} \\
\text { (CPCs) }\end{array}$ & $\begin{array}{l}\text { Thermoresponsive effect } \\
\text { of PNIPAM to increase the } \\
\text { fiber-matrix affinity of PVA } \\
\text { fibers }\end{array}$ & Petre et al. (2019) \\
\hline \multirow[t]{2}{*}{$\mathrm{PICN}$} & $\begin{array}{l}\text { Vita Enamic } \\
\text { (commercial } \\
\text { product) }\end{array}$ & Not mentioned & SEVNB & $1.09 \pm 0.05$ & Not mentioned & $\begin{array}{l}\text { Crack } \\
\text { deflection, } \\
\text { crack bridging }\end{array}$ & $\begin{array}{l}\text { Della Bona et al. } \\
\text { (2014) }\end{array}$ & & \\
\hline & $\begin{array}{l}49.5 w t \% \\
\text { TEGDMA + } 1 \text { wt } \% \\
\text { BPO + Bis-GMA }\end{array}$ & 12.3-18.4 wt\% & $\mathrm{ZrO}_{2}$ & $\begin{array}{l}\text { Immersing } \mathrm{ZrO}_{2} \\
\text { networks in the liquid } \\
\text { polymer, } \\
\text { polymerization under } \\
\text { the atmospheric } \\
\text { pressure by heat } \\
\text { treatment }\left(70^{\circ} \mathrm{C}, 10 \mathrm{~h}\right)\end{array}$ & SENB & $3.69 \pm 0.15$ & Not mentioned & $\begin{array}{l}\text { Polymer occupies pore } \\
\text { sites, increased } \\
\text { densification leads to } \\
\text { reduction in the detrimental } \\
\text { stress concentration }\end{array}$ & Li et al. (2017) \\
\hline \multirow[t]{2}{*}{ Others } & $\mathrm{Si}_{3} \mathrm{~N}_{4}$ & $1,3,5$ wt $\%$ & $\beta-\mathrm{CaSiO}_{3}$ & Pressureless sintering & SENB & $\begin{array}{l}2.3(3 \mathrm{wt} \% \\
\left.\mathrm{Si}_{3} \mathrm{~N}_{4}\right)\end{array}$ & $\begin{array}{l}1.1 \text { (pure } \beta \text { - } \\
\left.\mathrm{CaSiO}_{3}\right)\end{array}$ & Not mentioned & Pan et al. (2015) \\
\hline & L- (+)-Tar & $3,3.5,4,4.3 \mathrm{~g} / \mathrm{ml}$ & Brushite & $\begin{array}{l}\text { Set at room } \\
\text { temperature ( } 30 \mathrm{~min}) \text {, } \\
\text { then incubated in } \\
\text { distilled water } \\
\left(37^{\circ} \mathrm{C}, 24 \mathrm{~h}\right)\end{array}$ & $\begin{array}{l}\text { Three-point } \\
\text { bending method }\end{array}$ & $\begin{array}{l}0.6 \pm 0.07 \\
(0.5 \mathrm{M} \mathrm{L}-(+)-T a r \\
\text { at } 4.3 \text { powder- } \\
\text { to-liquid ratio) }\end{array}$ & Not mentioned & $\begin{array}{l}\text { L- (+)-Tar can decrease the } \\
\text { subunit size of brushite } \\
\text { crystals }\end{array}$ & Moussa et al. (2020) \\
\hline \multirow[t]{3}{*}{$\begin{array}{l}\text { Multi- } \\
\text { component }\end{array}$} & Leucite & $0,6,15,22$ vol\% & Six porcelains ${ }^{a}$ & Not mentioned & SEPB & $\begin{array}{l}1.23 \pm 0.12 \\
(\text { porcelain A) }\end{array}$ & $\begin{array}{l}0.71 \pm 0.05 \\
\text { (porcelain } \mathrm{Cb} \text { ); } \\
0.75 \pm 0.08 \\
\text { (porcelain V) }\end{array}$ & $\begin{array}{l}\text { Crack deflection around } \\
\text { leucite particles and } \\
\text { clusters }\end{array}$ & Cesar et al. (2005) \\
\hline & $\begin{array}{l}\text { Needle-like } \\
\text { fluorapatites }\end{array}$ & $0,1,3 w t \%$ & $\begin{array}{l}\text { Mica-based } \\
\text { glass-ceramics }\end{array}$ & $\begin{array}{l}\text { Casting and } \\
\text { subsequent heat } \\
\text { treatment }\end{array}$ & IF & $\begin{array}{l}3.1 \pm 0.3 \\
\text { (Glass 3) }\end{array}$ & $\begin{array}{l}0.8 \pm 0.1 \\
\text { (Glass 1) }\end{array}$ & $\begin{array}{l}\text { Frictional bridging and } \\
\text { pullout toughening }\end{array}$ & Xiang et al. (2007) \\
\hline & $\mathrm{MgO}$ & 0.5 wt $\%$ & $\begin{array}{l}\mathrm{Al}_{2} \mathrm{O}_{3} \text {-glass } \\
\text { composite }\end{array}$ & $\begin{array}{l}\text { Sintering at } 1,400^{\circ} \mathrm{C} \text { for } \\
2 \mathrm{~h} \text {, infiltrating the } \\
\text { molten glass into the } \\
\text { partially sintered } \\
\text { alumina compact }\end{array}$ & SENB & $\begin{array}{l}5.12 \pm 0.35 \\
\left(\mathrm{MgO}-\mathrm{Al}_{2} \mathrm{O}_{3} /\right. \\
\text { glass })\end{array}$ & $\begin{array}{l}0.58 \pm 0.13 \\
\text { (partially sintered } \\
\mathrm{Al}_{2} \mathrm{O}_{3} \text { ) }\end{array}$ & $\begin{array}{l}\text { Crack deflection, crack } \\
\text { bowing }\end{array}$ & Luo et al. (2002) \\
\hline
\end{tabular}

${ }^{2}$ Six porcelains: A (Ceramco I/Dentsply), B (Ceramco I//Dentsitply), C (Finesse/Dentsply), D (d.Sign//voclar), Cb (Cerabien/Noritake) and V Nitadur Alpha/Vita). 


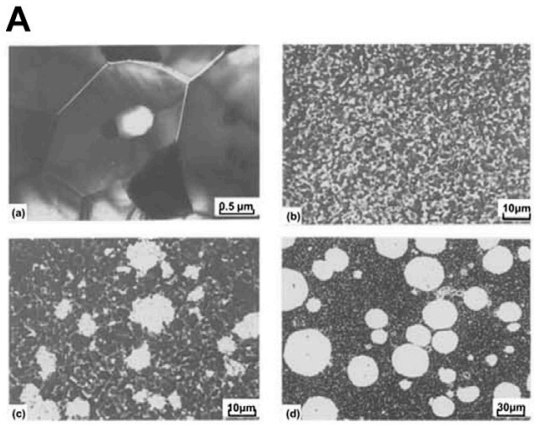

C

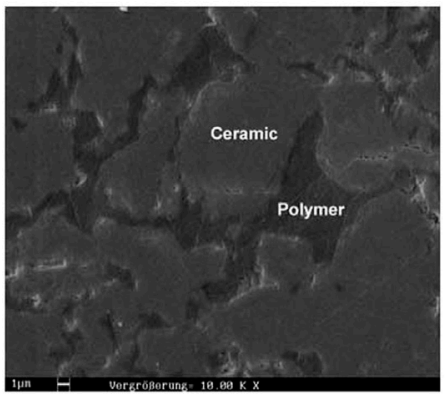

B

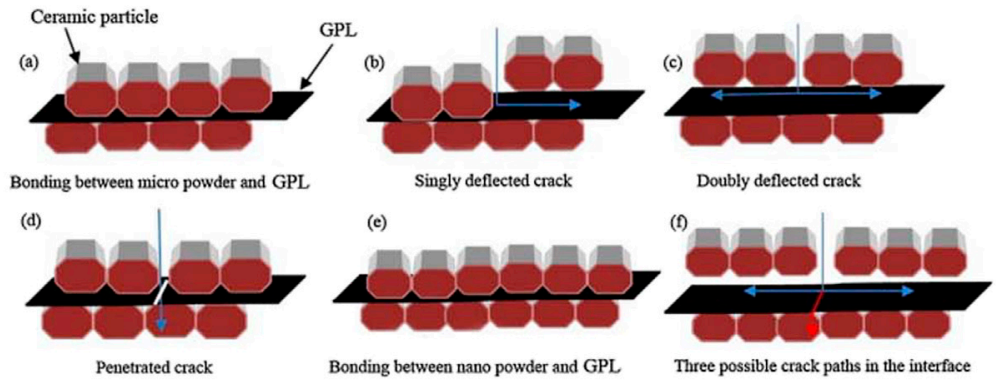

D
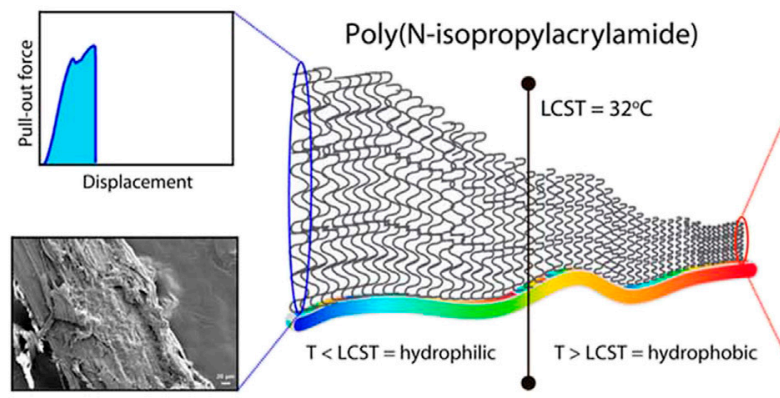

FIGURE 2 | Adding reinforcing fillers as second phase to toughen ceramics. (A), (a) transmission electron micrograph showing the microstructure for $\mathrm{Al}_{2} \mathrm{O}_{3}$ containing well-dispersed unstabilized $\mathrm{ZrO}_{2}$ particles; (b-d) scanning electron micrographs showing the microstructures of $\mathrm{Al}_{2} \mathrm{O}_{3}$ containing well-dispersed $\mathrm{PSZ}$ single crystals, TZP agglomerates and $\mathrm{Al}_{2} \mathrm{O}_{3}-\mathrm{ZrO}_{2}$ duplex structured composites, respectively (Wang and Stevens, 1989). (B) A schematic of the toughening mechanism in GPL toughened ceramic (Liu et al., 2012). (C) Polymer-infiltrated-ceramic-network structure (Coldea et al., 2013). (D) Thermoresponsive brushes facilitate effective reinforcement of calcium phosphate cements (Petre et al., 2019). PSZ, partially stabilized zirconia; TZP, tetragonal zirconia polycrastal; GPL, graphene platelet.

different toughening mechanisms acting simultaneously in the material. Apart from the above ingredients of Santos et al.'s study, Gommeringer et al. (2019) reinforced 1Y6Ce-TZP materials with different amounts of alumina and/or strontium hexaalumina by slip casting and pressureless sintering at different temperatures. Then these materials underwent accession of their mechanical properties, microstructure, phase composition, and lowtemperature degradation stability, which showed that they exhibited a high fracture resistance of $10-12 \mathrm{MPa} \mathrm{m}^{1 / 2}$. Partial substitution of the alumina dispersion by strontium hexaaluminate can improve the strength, while pres.erving toughness, hardness and low-temperature degradation resistance. The residual alumina provides grain growth inhibition. In summary, the improvement of structure or/and composition of the second phase is helpful to the toughening of $\mathrm{ZrO}_{2}-\mathrm{Al}_{2} \mathrm{O}_{3}$ ceramic.

$\mathrm{ZrO}_{2}$ and $\mathrm{Al}_{2} \mathrm{O}_{3}$ could also be added to toughen ceramics except for ZTA or ATZ. Gali et al. (2018) investigated $\mathrm{ZrO}_{2}$ toughened mica glass ceramics for dental restorations. It was recorded that mica glass ceramics with $20 \mathrm{wt} \%$ yttria stabilized zirconia (YSZ) reached Vickers hardness of $9.2 \mathrm{GPa}$, elastic modulus of $125 \mathrm{GPa}$, indentation toughness of $3.6 \mathrm{MPa} \mathrm{m} \mathrm{m}^{1 / 2}$, and chemical solubility of $30 \mathrm{~g} / \mathrm{cm}^{2}$ (well below the permissible limit), respectively. The phenomenon of transformation toughening of YSZ was observed in enhancing the toughness properties of ceramic. Because of its osseointegration property,
Calcium silicate $\left(\mathrm{CaSiO}_{3}, \mathrm{CS}\right)$, has been investigated as a bioactive biomaterial for bone tissue repair and replacement (Mehrali et al., 2014). Long et al. (2008) successfully fabricated $\beta-\mathrm{CaSiO}_{3} / \mathrm{ZrO}_{2}$ (3Y) nanocomposites via spark plasma sintering. Adding $\mathrm{ZrO}_{2}$ could enhance the phase transitional temperature of $\mathrm{CaSiO}_{3}$ and inhibit its phase transition. When the $\beta-\mathrm{CaSiO}_{3} / \mathrm{ZrO}_{2}$ mole ratio was 60/40, the fracture toughness and strength of the nanocomposites were as high as $4.08 \mathrm{MPa} \mathrm{m}^{1 / 2}$ and $395 \mathrm{MPa}$, respectively. Shuai et al. (2016) used zinc oxide whisker ( $\mathrm{ZnOw}$ ) to improve $\mathrm{CaSO}_{4} /$ bioglass scaffolds which were prepared via selective laser sintering (SLS). And the $\mathrm{ZnOw}$ improved fracture toughness and compression strength significantly. The combination of several toughening mechanisms, including whiskers pull-out, crack bridging, crack deflection, and crack branching, might be attributed to the increase of mechanical characteristics. Shirazi et al., (2014) investigated the effect of $\mathrm{Al}_{2} \mathrm{O}_{3}$ on $\mathrm{a}-\mathrm{CaSiO}_{3}$ ceramic and found that $15 \mathrm{wt} \%$ of $\mathrm{Al}_{2} \mathrm{O}_{3}$ addition at $1,250^{\circ} \mathrm{C}$ enhanced fracture toughness as well as hardness of $\mathrm{CaSiO}_{3}$.

Apart from $\mathrm{ZrO}_{2}-\mathrm{Al}_{2} \mathrm{O}_{3}$ system, other reinforcement-ceramic matrix systems have also been studied. Rasmussen et al. (2004) mixed core particles of cesium $\left(\mathrm{Cs}_{2} \mathrm{O}\right)$-containing synthetic leucite with two cesium-free matrix porcelains, a commercial porcelain (VP) and a synthesized leucite-based porcelain (NP). The toughness of both types of composite materials was dependent on $\mathrm{Cs}_{2} \mathrm{O}$ content of the added core particles, and 
the ceramic containing $0.75 \mathrm{~mol} \% \mathrm{Cs}_{2} \mathrm{O}$ reached a maximum toughness. The possible toughening mechanism was transformation toughening. Luo et al. (2002) modified glassinfiltrated $\mathrm{Al}_{2} \mathrm{O}_{3}$ with $0.5 \mathrm{wt} \% \mathrm{MgO}$. And the fracture toughness of this composite $\left(5.12 \mathrm{MPa} \mathrm{m} \mathrm{m}^{1 / 2}\right)$ is obviously higher than the partially sintered $\mathrm{Al}_{2} \mathrm{O}_{3}\left(0.58 \mathrm{MPa} \mathrm{m} \mathrm{m}^{1 / 2}\right)$, MgO-modified partially sintered $\mathrm{Al}_{2} \mathrm{O}_{3}\left(1.86 \mathrm{MPa} \mathrm{m} \mathrm{m}^{1 / 2}\right)$, or glass-infiltrated $\mathrm{Al}_{2} \mathrm{O}_{3}\left(3.91 \mathrm{MPa} \mathrm{m}{ }^{1 / 2}\right)$.

Most above mentioned second phases for toughening are metal compounds rather than metals alone. Besides, the research of Fujieda et al. (2012) and Uno et al. (2013) showed that metal nanocomposites (NPs) could also be used to increase the fracture toughness of ceramic. Fujieda et al. (2012) found that the addition of silver (Ag) and platinum (Pt) NPs improved the mechanical properties, including the fracture toughness and the Young's modulus, of commercial ceramic. The fracture toughness of AgNPs was higher than that of PtNPs. This could be due to the difference in positive compressive stress generation, which is projected to be greater for silver due to its higher coefficient of thermal expansion. Uno et al. (2013) researched the effects of adding AgNPs on the toughening of dental porcelain, Noritake Super (NS) Porcelain AAA. When the concentration of Ag in the solution was 500 and 1,000 ppm (Ag500 and Ag1000), toughness values of $1.54 \mathrm{MPa} \mathrm{m} \mathrm{m}^{1 / 2}$ and $1.51 \mathrm{MPa} \mathrm{m}^{1 / 2}$ were observed, respectively, which were higher than that of the control $\left(1.36 \mathrm{MPa} \mathrm{m}{ }^{1 / 2}\right)$. The inclusion of Ag500 and Ag1000 NPs, on the other hand, resulted in a color shift. Some AgNPs remained nanoparticles, whereas others interacted with matrix elements and turned into silver ions. As a result of the ion exchange reaction and differential thermal expansion of the silver metal nanoparticles, a residual compressive stress was created. Swain S.K et al. (2016) developed a novel biocompatible $\beta$-tricalcium phosphate $(\beta$-TCP)-based composited by reinforcing ceramic matrix with 30 vol\% of a biodegradable iron-magnesium (Fe$\mathrm{Mg}$ ) metallic phase, scilicet $\beta$-TCP-15Fe15 Mg and $\beta$-TCP$24 \mathrm{Fe} 6 \mathrm{Mg}$ (vol\%) composites. Both these composites had increasing mechanical properties.

\subsection{Non-Metal Reinforcements}

\subsubsection{Nanacarbon}

Nanocarbon materials have ever-increasing applications in ceramic toughening (Siddiqui et al., 2018), for displaying a special set of characteristics, namely high elasticity modulus, specific thermophysical, electrophysical and sorption properties (Falcao and Wudl, 2007). According to their spatial structures, nanocarbon materials can be classified as onedimensional, two-dimensional and three-dimensional materials (Hirsch, 2010).

One of the representatives of one-dimensional carbon structures is carbon nanotubes (CNTs), possessing a tubular structure made by rolling single/multi-layer graphite sheets. Large specific surface areas $\left(50-1,315 \mathrm{~m}^{2} \mathrm{~g}^{-1}\right)$, a high aspect ratio (as they have their diameters at the nano-scale but their lengths, are, by contrast, at the micron-scale), high tensile strength, high resilience, and flexibility are its typical properties (Dong et al., 2012). On the basis of this physical structure, carbon nanotubes can be single-walled carbon nanotubes (SWNTs) (single tube)-or multi-walled carbon nanotubes (MWNTs) (concentric cylinders of carbon) (T. F. Kuo et al., 2001; Akasaka et al., 2006). Lahiri et al. (2010) synthesized MWNTs reinforced hydroxyapatite (HA) composite via spark plasma sintering. The fracture toughness and elastic modulus increased by 92 and 25\%, respectively, compared to the HA matrix without CNT, which is due to the uniform distribution of $4 \mathrm{wt} \% \mathrm{CNTs}$ in the HA matrix, good interfacial bonding and fine HA grain size. It was explained that interfacial shear strength and pull-out energy of MWNTs from HA contributed to toughening.

Graphene is a leading nanomaterial of two-dimensional carbonaceous materials (Allen et al., 2010). Compared to monolayer graphene, graphene platelets (GPLs), also referred as graphene nanoplatelets (GNPs), graphene nanosheets (GNS), or multilayer graphene nanosheets (MGN), are formed by several layers of graphene with thickness of up to100 nm (Siddiqui et al., 2018). GPLs have not only a large specific surface area, but also two dimensional high aspect ratio, as well as outstanding mechanical properties, which make them excellent potential nanofillers in composite materials (Liu Y et al., 2013). For dental ceramics, Liu et al. (2012) carried out a study on graphene platelet/zirconia-toughened alumina (GPL/ZTA) composites, which were sintered at different temperatures via spark plasma sintering. Measured by the single-edge notched beam method, it is found that at $1,550^{\circ} \mathrm{C}$, GPL/ZTA composites reached almost full density, maximum fracture toughness (with $40 \%$ improvement) and hardness. Multi-toughening mechanisms, such as pull out, bridging and crack deflection, were observed. In the bone repair area, Mehrali et al. (2014) reinforced $\mathrm{CaSiO}_{3}$ ceramic with graphene nanoplatelets (GNPs) using hot isostatic pressing (HIP) method at $1,150^{\circ} \mathrm{C}$. The homogeneous distribution of $1 \mathrm{wt} \%$ GNP in the $\mathrm{CaSiO}_{3}$ matrix, fine $\mathrm{CaSiO}_{3}$ grain size and high densification helped to increase the fracture toughness, brittleness index and hardness by 130,40 and $30 \%$, respectively, in contrast to the $\mathrm{CaSiO}_{3}$ matrix without GNPs. Similar to Liu et al. (2012), the toughening mechanisms also included crack bridging, pull-out, branching and deflection.

An important derivative of graphene is graphene oxide (GO), consisting of graphene sheets covered with oxygen-based functional groups (Raslan et al., 2020). Utilized in dental ceramic toughening, Zhang et al. (2020) distributed GO uniformly in $3 \mathrm{Y}-\mathrm{ZrO}_{2}$ powders, forming the $\mathrm{C}-\mathrm{O}-\mathrm{Zr}$ bond during the sintering process. As a result, the fracture toughness increased $40.9 \%\left(8.95 \pm 0.59 \mathrm{MPa} \mathrm{m} \mathrm{m}^{1 / 2}\right)$ when adding $0.1 \mathrm{wt} \% \mathrm{GO}$, and the flexural strength improved up to $200 \%(1,489.96 \pm 35.71 \mathrm{MPa})$ when adding $0.15 \mathrm{wt} \% \mathrm{GO}$, in comparison to raw $3 \mathrm{Y}-\mathrm{ZrO}_{2}$ ceramics. The toughening mechanisms, namely crack deflection, crack bridging, and GO put-out are found.

\subsubsection{Polymer}

Calcium phosphate cements (CPCs) are a class of injectable bone substitute bioceramics (Kucko et al., 2019). To toughen this kind of bioceramic, Kucko et al. (2019, 2020) added surface-modified poly (vinyl alcohol) (PVA) fibers to CPCs and improved 


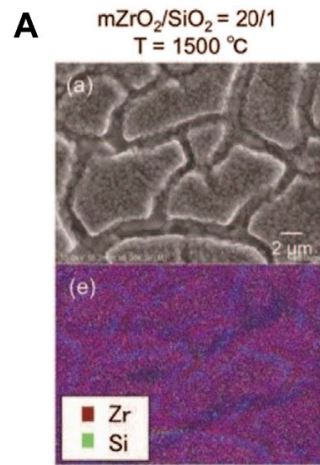

B

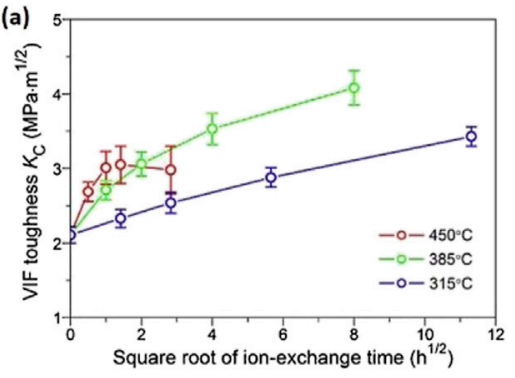

$\mathrm{mZrO}_{2} / \mathrm{SiO}_{2}=10 / 1$
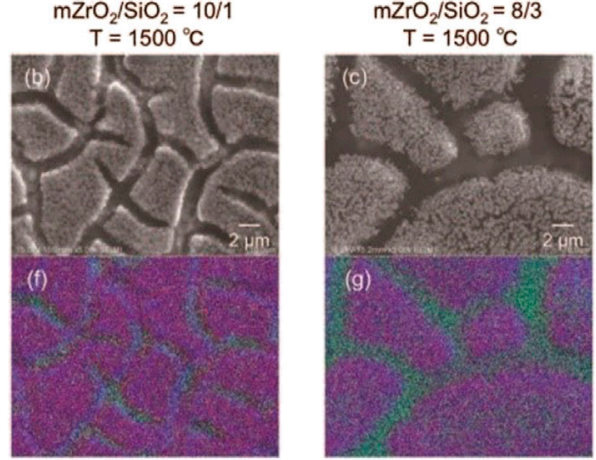

(b)

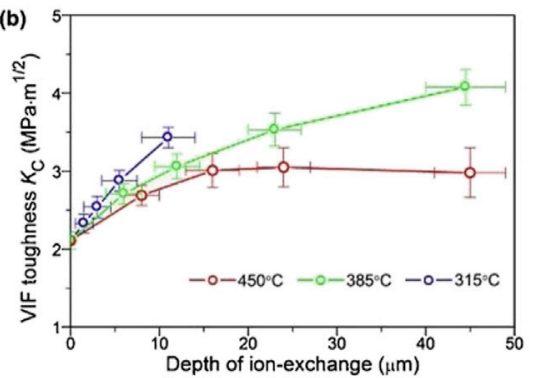

$\mathrm{mZrO} / \mathrm{SiO}_{2}=6 / 5$

$\mathrm{T}=1500^{\circ} \mathrm{C}$

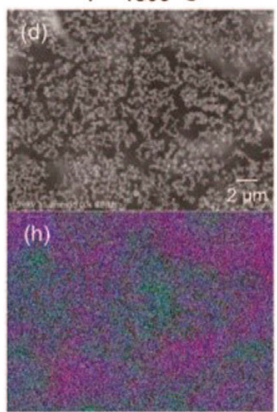

C

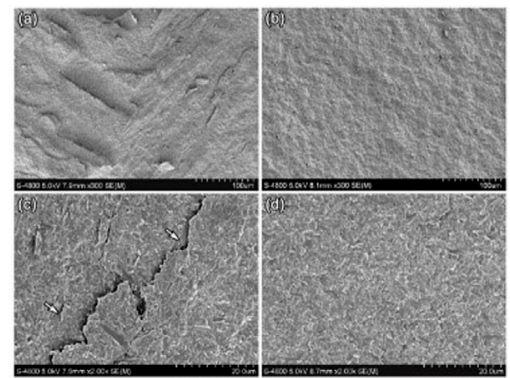

FIGURE 3 | Toughening ceramics by coating, chemical and thermal surface treatments. (A) Monoclinic $\mathrm{ZrO}_{2}$ and $\mathrm{SiO}_{2}$ particle coating, toughening highly translucent $\mathrm{ZrO}_{2}$. (a-d) scanning electron micrographs, (e-h) $\mathrm{Zr}$ and Si elemental mapping of samples $\mathrm{coated}$ with $\mathrm{mZrO}_{2} / \mathrm{SiO}_{2}$ and heat treated at $1,500^{\circ} \mathrm{C}(\mathrm{Uno}$ et al., 2020). (B) lon-exchange toughened lithium disilicate glass-ceramic. Changing tendencies of VIF toughness of the glass-ceramic with increasing (a) the ion-exchange time and (b) the depth of $\mathrm{Li}^{+} / \mathrm{Na}^{+}$exchange obtained, at 450, 385 and $315^{\circ} \mathrm{C}$, respectively, in a pure $\mathrm{NaNO}_{3}$ bath ( $\mathrm{Li}$ et al., 2020). (C) Scanning electron microscope fractographs of the lithium disilicate glass-ceramic: (a,c) in annealing state; (b,d) tempered in $250^{\circ} \mathrm{C}$ silicone oil. Reproduced with permission from Li et al. (2021). VIF, Vickers indentation fracture.

toughness and flexural strength of CPCs by more than 435 -fold and 3 -fold, respectively. The fiber-matrix affinity is thought to be paramount in designing highly toughened CPCs. So, the surface of PVA fibers was modified to improve their hydrophilicity and affinity to the CPC matrix, which facilitated energy dissipation during fracture of CPCs. Furthermore, other crack-arresting mechanisms may also play a significant role in mechanically reinforcing CPCs, because the fracture toughness improved significantly even for CPCs reinforced with fibers of lengths greater than their critical fiber embedment length. The surface of PVA fibers could be further modified with environmentally responsive materials to improve their ceramic toughening effect. Petre et al. (2019) functionalized the surface of PVA fibers with thermoresponsive poly ( $\mathrm{N}$-isopropylacrylamide) brushes of tunable thickness to enhance simultaneously fiber dispersion and fiber-matrix affinity. At temperatures above their lower critical solution temperature of $32^{\circ} \mathrm{C}$, these brushes shifted from hydrophilic to hydrophobic. This dual thermoresponsive shift favored fiber dispersion throughout the hydrophilic CPCs (at $21^{\circ} \mathrm{C}$ ) and toughened these cements when reaching their hydrophobic state $\left(\right.$ at $37^{\circ} \mathrm{C}$ ). And fibers at $37^{\circ} \mathrm{C}$ showed nearly double reinforcement efficacy than that of $21^{\circ} \mathrm{C}$.

Different from conventional dispersed-filler toughened ceramics, a kind of dual-phase material consists of two continuous interpenetrating networks, namely polymer infiltrated ceramic network (PICN) material, has been developed to emulate the properties and physical properties of natural teeth (Mainjot et al., 2016). PINCs can be sorted as interpenetrating phase composites, which possess a threedimensional interconnected geometry. The two continuous networks in PICNs are porous pre-sintered ceramic networks and infiltrated polymers (commonly resin for dental applications), which are shown in Figure 1 (Coldea et al., 2013). Crack propagation is often limited in PICNs due to interfacial crack deflection, which is caused by the existence of two linked phases. By bridging the cracks introduced to the other phase, the phase with the higher strain to failure improves fracture resistance (Horvitz et al., 2002; Nalla et al., 2003). Furthermore, Feng et al. (2003) found that the reinforcing phase could distribute stresses more efficiently in all directions in interpenetrating networks. Released in 2012, Vita Enamic (Vita Zahnfabrik, Bad Säckingen, Germany) is the successful representative of commercial PICN, consisting of $86 \mathrm{wt} \%$ or $75 \mathrm{vol} \%$ inorganic phase and $14 \mathrm{wt} \%$ or $25 \mathrm{vol} \%$ organic phase (Swain M. V. et al., 2016). Della Bona et al. (2014) examined the microstructure and fracture toughness $\left(\mathrm{K}_{\mathrm{Ic}}\right)$ of Vita Enamic, via scanning electron microscopy (SEM) and V-notched-beam test, respectively. The microstructure was shown in Figure 3 and the $\mathrm{K}_{\mathrm{Ic}}$ was $1.09 \pm 0.05 \mathrm{MPa} \mathrm{m}^{1 / 2}$. El Zhawi et al. (2016) tested the resistance to fatigue fracture and wear of Vita Enamic and used step-stress accelerated life testing to show that failure could only be found under very high loads $(>1000 \mathrm{~N})$. The result inferred 
that it was unlike for the Enamic posterior crowns to experience early clinical abrupt fractures, which may only happen under extremely high traumatic loads when the radius of the antagonist cusp was relatively small. Swain M. V et al. (2016) investigated seven kinds of PICN materials, whose single edge V-notched bend (SEVNB) fracture toughness varied from 0.82 to $4.94 \mathrm{MPa}$ $\mathrm{m}^{1 / 2}$. And they indicated that factors influencing the extent of the crack included the residual stress in the resins, the bonding quality with the ceramic matrixes, the extent of polymeric conversion of the monomer or oligomer, as well as the yield stress and strain to failure of the bridging polymer. Li et al. (2017) fabricated a polymer-infiltrated zirconia ceramic for dental crown restoration, with zirconia network porosity varying from 46.3 to $34.7 \%$ and the relevant polymer content ranging from $18.4 \mathrm{wt} \%$ to $12.3 \mathrm{wt} \%$. At pre-sintered temperature was $1,150^{\circ} \mathrm{C}$, the facture toughness was $3.69 \pm$ $0.15 \mathrm{MPa} \mathrm{m}^{1 / 2}$, about twice or three times higher than those of the polymer-infiltrated feldspar ceramics.

\subsubsection{Others}

On the periodic table of the elements, silicon and carbon are both on the fourth group, which indicates that silicon may have similar effect as carbon and could also be used in ceramic toughening. Silicon nitride $\left(\mathrm{Si}_{3} \mathrm{~N}_{4}\right)$ is a kind of ceramics with high performance characterized by fracture toughness, high wear resistance and low coefficient of friction (Pezzotti, 2019). Pan et al. (2015) doped different content of $\mathrm{Si}_{3} \mathrm{~N}_{4}$ in $\beta-\mathrm{CaSiO}_{3}$ ceramics at the sintering temperature ranging from $1,000^{\circ} \mathrm{C}$ to $1,150^{\circ} \mathrm{C}$. Through being oxidized to form $\mathrm{SiO}_{2}, \mathrm{Si}_{3} \mathrm{~N}_{4}$ can be successfully used as sintering additive. And with $3 \mathrm{wt} \% \mathrm{Si}_{3} \mathrm{~N}_{4}$ addition, the $\beta-\mathrm{CaSiO}_{3}$ ceramics sintered at $1,100^{\circ} \mathrm{C}$ got fracture toughness of $2.3 \mathrm{MPa} \mathrm{m}{ }^{1 / 2}$, flexural strength of $157.2 \mathrm{MPa}$ and hardness of $4.4 \mathrm{GPa}$, which was much higher than that of pure $\beta$ $\mathrm{CaSiO}_{3}$ ceramics $\left(1.1 \mathrm{MPa} \mathrm{m}{ }^{1 / 2}, 41.1 \mathrm{MPa}\right.$ and 1.0 GPa).

In organic compounds, chirality is a very important property, which seems to also play a role in ceramic toughening materials. Moussa et al. (2020) showed that the addition of homochiral L-(+)-tartaric acid (Tar) increased the mechanical properties of brushite bioceramics by decreasing their crystal size, following the classic Hall-Petch strengthening effect; however, D-(-)-tartaric acid displayed the opposite effect. In comparison with brushite bioceramics without additives, adding L-(+)-Tar increased the fracture toughness $\left(0.3 \mathrm{MPa} \mathrm{m}^{1 / 2}\right)$ and compressive strength $(26 \mathrm{MPa})$ of this ceramic composite by 62 and $33 \%$, respectively.

\subsection{Multi-Component Reinforcements}

Both metal and non-metal reinforcements have their advantages and disadvantages. Metal fillers like $\mathrm{ZrO}_{2}$ or $\mathrm{Al}_{2} \mathrm{O}_{3}$ have esthetic color but unexpected LTD or lower strength, while non-metal fillers like nanocarbon materials possess high elasticity modulus but susceptible to high sintering temperature. Proper combination of metal and non-metal components could be a promising approach to toughen bioceramics. Cesar et al. (2005) modified six kinds of dental porcelains with the addition of leucite. Leucite $\left(\mathrm{K}_{2} \mathrm{O} \cdot \mathrm{Al}_{2} \mathrm{O}_{3} \cdot 4 \mathrm{SiO}_{2}\right)$ is a potassium-aluminum-silicate phase that can be incorporated into the dental porcelain in two ways: the incongruent melting of potash feldspar $\left(\mathrm{K}_{2} \mathrm{O} \cdot \mathrm{Al}_{2} \mathrm{O}_{3} \cdot 6 \mathrm{SiO}_{2}\right)$ or as a synthetic powder. For the materials investigated, the higher the leucite content in the porcelain, the higher the fracture toughness, implying that they would have better clinical performance. Xiang et al. (2007) fabricated mica-based glass-ceramics containing needle-like fluorapatites. They found that the ceramics with higher fluorapatite content (mainly containing $\mathrm{CaO}$ and $\mathrm{P}_{2} \mathrm{O}_{5}$ ) presented higher fracture toughness and Vickers hardness, due to a large amount of needle-like fluorapatite crystals and the fine microstructure. Luo et al. (2002) fabricated MgO-modified glass infiltrated $\mathrm{Al}_{2} \mathrm{O}_{3}$ for CAD/CAM. There are two main functions of glass infiltration: the first is to eliminate almost all porosities, which are prone to crack initiation; secondly, the difference in the coefficients of thermal expansion between $\mathrm{Al}_{2} \mathrm{O}_{3}$ and glass produces compressive stresses, further enhancing strength at the $\mathrm{Al}_{2} \mathrm{O}_{3}$-glass interface. Furthermore, $\mathrm{MgO}$ improved grain size uniformity, controlled grain growth, and promoted homogeneous wetting of $\mathrm{Al}_{2} \mathrm{O}_{3}$ grains by the liquid through an alternation in interfacial energies, allowing the manufacture of high-density ceramics.

\section{SURFACE MODIFICATION OF CERAMIC}

Surface modification mainly includes coating, chemical and thermal surface treatments (Kelly et al., 1996) (Figure 3).

Coating is also an important and widely used method in surface modification. Based on the toughening mechanism of strengthened glass, where the outer surface is compressed to impede breakage because of the outside stress, Uno et al. (2020) used a dispersion containing $\mathrm{mZrO}_{2}$ and $\mathrm{SiO}_{2}$ as a surface coating agent for partially stabilized zirconia (PSZ). When the crystal phase changed from tetragonal to monoclinic, the $\mathrm{mZrO}_{2}$ underwent volume change to generate a compressive stress layer on the material's surface. The $\mathrm{SiO}_{2}$ serves as a binder to improve wettability and to accelerate the sintering of $\mathrm{mZrO}_{2}$.

Because many (but not all) ceramic and glass structures collapse due to surface imperfections, and surface compressive stresses must be exceeded before cracks can propagate, this approach permits treated structures to withstand higher loads before failing (Kelly et al., 1996). Ion-exchange has become a major method for chemical toughening, the mechanism of which could be attributed to "stuffing effect"-—exchange of smaller alkaline metal ions in glasses with larger ones from molten salt baths can cause residual compressive stresses on the surfaces at temperatures below the glass transition temperatures ( $\mathrm{Tg}$ ), resulting in significant toughening of the glasses under the condition without sacrificing their light transmittance (translucency) (Li et al., 2020). This mechanism indicates that ion-exchange is suitable for ceramics containing glass (glassceramics), dual-phase materials consisting of glassy matrix and embedded crystalline phases (Deubener et al., 2018). They could combine the attractive properties of crystalline ceramics with those of glasses. Ion-exchange has been a popular way to strengthen monolithic silicate glasses containing alkaline oxides (Fillery and Lange, 2007; Jiang et al., 2017). In Li 
et al.'s study (Li et al., 2020), a multi-component lithium disilicate (LD) glass-ceramic with interlocking microstructure consisting of rod-like LD crystals and glassy matrix was ion-exchanged over wide temperature and time range in pure $\mathrm{NaNO}_{3}$ or mixed $\mathrm{NaNO}_{3}$ and $\mathrm{KNO}_{3}$ baths below the glass transition temperature. Moreover, an experimental dual ion exchange toughening treatment was developed for feldspathic porcelains that surpassed the toughening of a single ion treatment and survived air abrasion (Kelly et al., 1996).

Thermal treatment could also effectively toughen glass ceramics. Li et al. (2021) toughened lithium disilicate (LD) glass-ceramic by tempering processes, which were conducted by heating the bar-like and disc-like specimens to a temperature below the dynamic softening point, and then rapid cooling in silicone oil with different temperatures ranging from room-temperature to $300^{\circ} \mathrm{C}$ to regulate the cooling rate. The specimens were effectively toughened, but the bar-like specimen displayed obvious anisotropy in fracture toughness, attributed to the "edge cooling effect" of the specimens with uneven geometry.

Comparing the chemical and thermal toughening methods, the former has the particular benefit of efficiently toughening glass-ceramic products of nearly any geometry and thickness (Donald, 1989), which is critical for many types of medical devices with customized geometries and thicknesses. However, this toughening effect could be susceptible to contact damage during service $(\mathrm{Gy}, 2008)$, or it will be completely lost in clinical practice by surface grinding during the manufacture of devices, like dental restorations, owing to the small micron level case depth of ion-exchange (Fischer et al., 2008). On the contrary, the thermal tempering could create significantly deeper surface layers with residual compressive stresses (millimeter level), making the toughening effect less susceptible to contact damage (Fan et al., 2016). Unfortunately, it was observed that the residual stresses created by fast cooling were geometry-dependent, and that they might vary in different directions as a result of differences in heat exchange conditions caused by different geometries (Al-Amleh et al., 2014). Therefore, mechanical anisotropy of the tempered glass-ceramics would emerge from these geometry-dependent residual stresses, lowering their mechanical reliability.

\section{IMPROVING MANUFACTURING PROCESSES}

The fabrication of ceramics is concerned with powder preparation, green forming and the densification processes (Wang and Stevens, 1989): (I) powder preparation processes include mechanical mixing, sol-gel processes, partial chemical methods, chemical vapor deposition (CVD) process, rapid solidification, hydrothermal oxidation, wear of $\mathrm{ZrO}_{2}$ milling media, etc. (II) forming methods mainly involve regular sintering, spark plasma sintering (SPS) (Han et al., 2017), hot pressing, hot isostatic pressing and so on.

Considering optimization of powder preparation processes, grain sizes could affect mechanical properties of ceramics. Larger particles undergo the martensitic $\mathrm{t}$-to- $\mathrm{m}$ transformation more quickly than smaller particles in partially stabilized $\mathrm{ZrO}_{2}$ and $\mathrm{Al}_{2} \mathrm{O}_{3}-\mathrm{ZrO}_{2}$ composites (Heuer et al., 1982). By decreasing the corresponding grain sizes and enhancing the homogeneity of the phase dispersion, the mechanical characteristics of $\mathrm{ZrO}_{2} / \mathrm{Al}_{2} \mathrm{O}_{3}$ dispersion ceramics may be significantly improved. Bartolomé et al. (2016) prepared nanoparticles with an intraparticular phase distribution of $\mathrm{Zr}_{(1-\mathrm{x})} \mathrm{Al}_{\mathrm{x}} \mathrm{O}_{(2-\mathrm{x} / 2)}$ and $(\gamma-, \delta-) \mathrm{Al}_{2} \mathrm{O}_{3}$ by the simultaneous gas phase condensation of $\mathrm{CO}_{2}$ laser covaporized (CoLAVA) zirconia and alumina raw powders. In general, the CoLAVA nanoparticles are spherically shaped, narrowly size-distributed, crystalline, and merely softly agglomerated by weak van der Waals forces. And fracture toughness of the CoLAVA composite significantly exceeds the ones of the wet mechanically mixed $\mathrm{Al}_{2} \mathrm{O}_{3} / \mathrm{ZrO}_{2}$ reference powder (WM) by $45 \%$, and reaches levels of $6.8 \mathrm{MPa} \mathrm{m}^{1 / 2}$.

In addition to particle sizes, degree of crystallization also affects ceramic toughness, which could be referred to as crystallization toughening. Serbena et al. (2015) employed stoichiometric lithium disilicate glasses as a model system, which were crystallized using two-stage heat treatments that were carefully developed and controlled to yield varied crystallized volume fractions while maintaining a constant grain size of around $12 \mu \mathrm{m}$. The fracture toughness of a completely crystalline sample improves about fivefold, from 0.75 to $3.5 \mathrm{MPa} \mathrm{m}^{1 / 2}$. Crack deflection, crack bowing and trapping, and crack bridging are three methods that contribute to toughening.

Regarding the densification of materials, sintering methods influence the final properties and microstructure of the obtained material (Chaim, 2008; Nevarez-Rascon et al., 2009; Faga et al., 2012). Magnani and Brillante (2005) found that post-hot isostatic pressing treatment resulted in the formation of a small amount of monoclinic phase in $\mathrm{Al}_{2} \mathrm{O}_{3}-\mathrm{ZrO}_{2}$ composites that decreased fracture toughness. Gil-Flores et al. (2020) densified ATZ nanocomposites via nonconventional microwave sintering technology at relatively low temperatures $\left(1,200\right.$ and $\left.1,300^{\circ} \mathrm{C}\right)$. The results indicated that the density increased as the sintering temperature was higher, which lead to improved mechanical properties, reaching a maximum fracture toughness (5.7 \pm $\left.0.3 \mathrm{MPa} \mathrm{m}^{1 / 2}\right)$ and hardness $(18.4 \pm 0.4 \mathrm{GPa})$.

\section{TOUGHENING MECHANISMS}

In short, the major toughening mechanism of ceramics is to absorb energy of crack initiation or propagation to impede ceramic fracture. Different toughening methods have their specific mechanisms, but may also share similar mechanisms, vice versa, one toughening method typically contains several mechanisms at the same time (Figure 4).

\subsection{Fine-Grained Toughening}

The underlying toughening mechanism of controlling grain size is mainly fine-grained toughening. The reinforcement fillers located at the grain boundary provide a pinning effect, which can not only inhibit grain growth but also promote filler dispersion (Karthiselva et al., 2018). The toughening effect of 

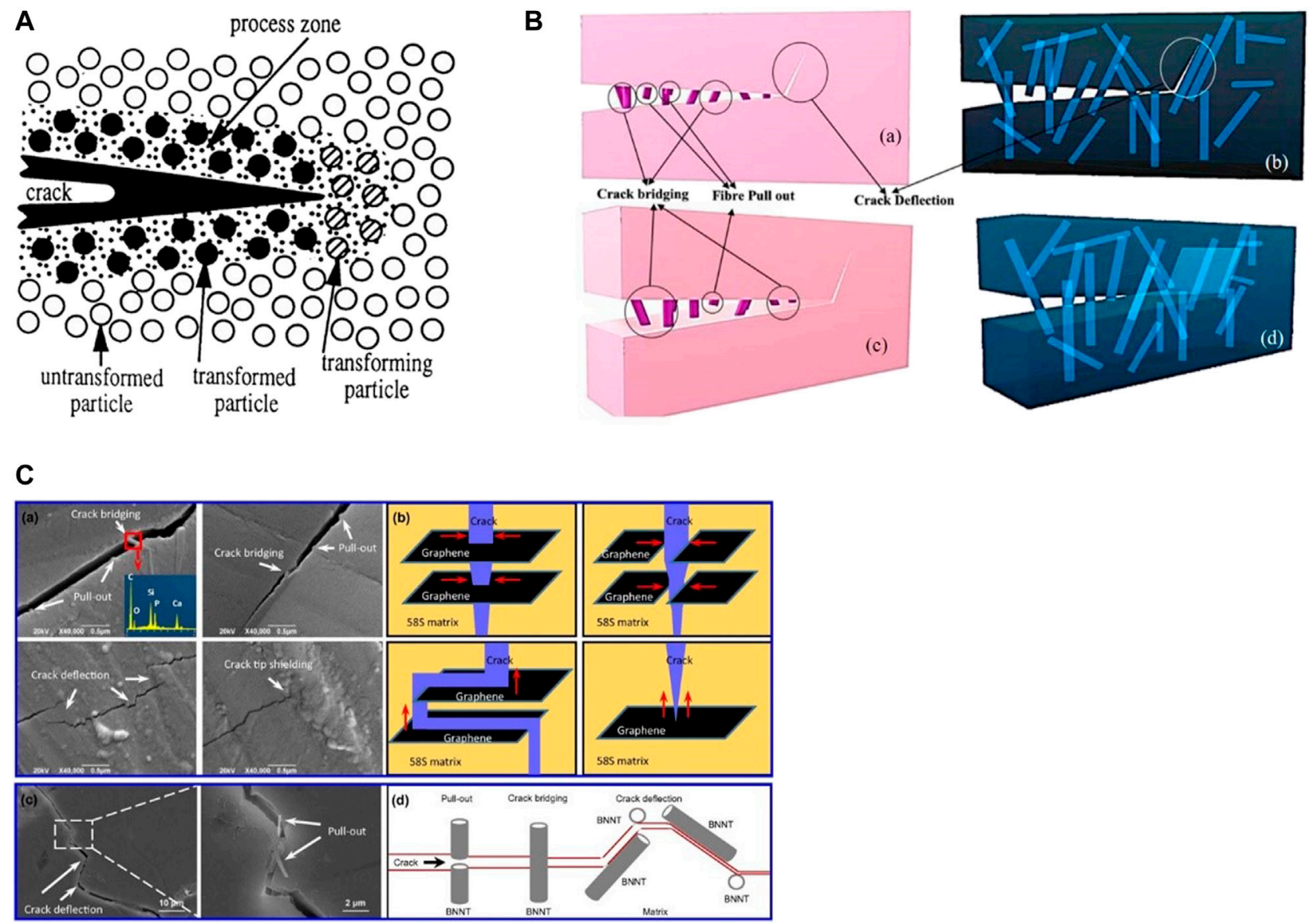

FIGURE 4 | Toughening mechanisms in ceramic composites. (A) Representation of stress-induced phase transformation toughening process (Piconi and Maccauro, 1999). (B) A typical representation of strengthening and toughening by fibers. (a,c) represent two views of crack in a body being perturbed by fibers, (b,d) represents the see-through image of the body presented in (a,c) (Siddiqui et al., 2018). (C) Reinforcing mechanisms of low-dimensional nanomaterials (LDNs) in bioactive ceramics. (a,c) scanning electron micrographs and (b,d) schematic diagram showing the pull-out, crack bridging, crack deflection and crack tip shielding mechanisms (Gao et al., 2017).

fine-grain reinforcement is quite obvious according to the HallPetch formula. And the vital factors influencing the efficiency of fine-grained toughening include the content of second phase, the geometric shape, as well as the temperature and impurities (Liu et al., 2020).

\subsection{Stress-Induced Phase Transformation Toughening}

Transformation toughening mainly occurs in ceramics consisting of $\mathrm{ZrO}_{2}$, and could sometimes happen for other components as well. When an external tensile stress is applied to a crack tip, metastable tetragonal $\mathrm{ZrO}_{2}$ inclusions scattered in a ceramic matrix are known to convert to their thermodynamically stable monoclinic form (R. C. Garvie and Hannink, 1975; Lange, 1982). The stress to initiate transformation is lower than the fracture stress, and transformation happens preferentially and proceeds until the transformable $t$ phase is exhausted (Hannink et al., 2000). Therefore, the phase transformation, which is accompanied by a volume expansion of $4 \%$ and shear strain of $6 \%$, creates a compressive stress that slows and eventually stops the crack propagation, while the strain energy associated with any net shear component of the transformation strain in the transformation zone contributes an effective increase in the energy of fracture (Wang and Stevens, 1989). The contribution of stress-activated transformation, $\Delta \mathrm{K}_{\mathrm{cT}}$, to the toughness is usually expressed in the form

$$
\Delta \mathrm{K}_{\mathrm{c} T}=\frac{\eta E^{*} e_{T} V_{f} h^{1 / 2}}{1-v}
$$

Where $\eta$ is a factor depending on the zone shape at the crack tip and the nature of the stress field in that zone, $E^{*}$ the effective modulus of the material, $e_{T}$ the dilatational strain, $V_{f}$ the transformed volume fraction of the particles, $h$ the width of the transformation zone from the crack surface, and $v$ the Poisson ratio (Hannink et al., 2000).

\subsection{Microcrack Toughening}

Microcracks in ceramic materials can be subdivided as residual microcracks and stress-induced microcracks. Take the $\mathrm{ZrO}_{2}$ 
ceramic as an example, the residual microcracks are those caused by the volume expansion and shear strain associated with t-to-m phase transformation mentioned in section above, while the stress-induced microcracks are from the volume expansion and shear strain associated with the subsequent stress-induced transformation during fracture process. During phase transformation, tangential stresses are generated around the transformed $\mathrm{m}-\mathrm{ZrO}_{2}$ particles. Microcrack toughening mainly relies on two shielding sources. One is the main-crack and microcrack interaction which causes stress redistribution ahead of the main-crack tip and thus lowers the continuum stiffness of the microcracked material. The other is the stress redistribution at the main-crack tip due to the release of residual stress when a microcrack is nucleated (Hutchinson, 1987). Microcracks form at the intersections of the fillers and the matrix as a result of this, which can absorb fracture energy by extending in the stress field of a propagating crack or deflecting the propagating crack (Wang and Stevens, 1989). Microcracks behind the main-crack tip provide the most shielding, while microcracks ahead of the main-crack tip contribute no shielding effect. What's more, compressive normal residual stress may attribute to an antishielding effect at the main-crack tip, which should be paid attention for the design of ceramic materials (Chen, 2005).

\subsection{Crack Deflection and Crack Bifurcation}

Crack deflection refers to the condition that the reinforcement fillers will generally deflect the crack at a certain angle when the crack propagates in the ceramic matrix and meets fillers (Zou et al., 2018). So the fracture energy of crack propagating is consumed and the rate of crack propagating is reduced, as a result, the fracture toughness is increased (Zou et al., 2018). Specifically, deflection toughening occurs whenever interaction between the crack front and the minor phase produces a nonplanar crack, subject to a stress intensity lower than that experienced by the corresponding planar crack. And the nonplanar crack arises either from the existence of weakened interfaces or from residual strains present in the material. Considering shape, the rod of high aspect ration is the most effective morphology to deflect propagating cracks, which could account for four-fold increases in fracture toughness (Faber and Evans, 1983).

Crack bifurcation occurs at the matrix-filler interface. The primary crack runs vertically, whereas the bifurcation crack runs parallel to the matrix-filler interface. When a micro-crack forms at the end of the interface and can be deflected at $90^{\circ}$ to extend to the ceramic matrix, the bifurcation crack is ended, which helps stress propagation at the corner. The new fracture then spreads parallel to the primary crack (Cheng et al., 2018).

\subsection{Crack Bridging and Pull-Out}

Take advantage of crack bridging, several types of discontinuous reinforcing fillers have been successfully applied to form toughened ceramics including second-phase whiskers (Becher, 1990), platelets (Becher, 1991), as well as elongated, plate-like, and large matrix grains (Himsolt et al., 1979; Mussler et al., 1982). Crack bridging happens during ceramic cracking. The two ends of the reinforcement filler link the crack surface and begin to distort as the distance between the two crack walls grows, which imposes a closure force on the crack. The two segments of fillers are tightly linked to the matrix throughout the process and consume the crack propagation energy.

Before reaching the reinforcement's deformation limit, a pullout may occur, consuming the fracture energy, or filler-matrix debonding with crack bridging may occur. Defects in this mechanism alter the mobility of fillers, which in turn affects energy dissipation (Liu et al., 2020). The extent of pullout of discontinuous reinforcement is commonly quite limited, which is due both to the short length of such phases and the fact that bonding and clamping stresses often discourage pull out. However, pullout cannot be ignored as even short pull-out lengths contribute to the toughness achieved (Li, 2012).

\section{CURRENT CHALLENGES AND FUTURE OUTLOOK}

Although large amount of toughening strategies have been proposed for biomedical ceramic, there still exists challenges needed to be overcome, such as biodegradability and biocompatibility, as well as trade-off between toughness and strength. These challenges indicate that there is broad developing space of ceramic toughening for biomedical use, and future outlook is put forward to shed light on this attractive research field.

\subsection{Influence of Fracture Toughness of Ceramic on Degradability, In Vitro and In Vivo Performance}

Biomedical applications require ceramic materials with excellent biocompatibility to ensure device acceptance and patient safety, which is the prior recommend compared with toughness. First, no short- or long-term cytotoxicity is expected for biomaterials. Nieto et al. (2017) reviewed studies on graphene reinforced ceramic matrix composites (GNP-CMCs) and found all studies showed no cytotoxic effects induced by GNPs. After evaluating the long-term biocompatibility of a new ZTA, mainly in terms of DNA damage, mutagenicity and cancerogenetic potential in mammalian cells, Maccauro et al. (2009) found no long-term carcinogenic effect. Besides, toughening ceramic strategies should not affect the function of cells. In in vitro tests, the $\beta$-TCP$15 \mathrm{Fe} 15 \mathrm{Mg}$ composite fabricated by Swain S. K et al. (2016) was shown to support the attachment and proliferation of osteoblast and endothelial cells and the cells exhibited characteristic markers for bone formation and angiogenesis, respectively. For the second phase addition strategy, proper concentration of reinforcement is a critical factor to be controlled. According to the evaluation of Zhang et al. (2019), hydroxyapatite ceramic with $3 \mathrm{wt} \% \mathrm{ZrO}_{2}$ showed good cell viability and no cytotoxicity, and the mouse bone mesenchymal stem cells continued to proliferate on the ceramic surface observed for 5 days. Shuai et al. (2016) doped $\mathrm{ZnO}$ whisker $(\mathrm{ZnOw})$ in the ceramic matrix, and cells attachment, extension and interconnection behavior of MG63 cells were enhanced with the $\mathrm{ZnOw}$ increasing from $1 \mathrm{wt} \%$ to $5 \mathrm{wt}$ 
\%. However, when $\mathrm{ZnOw}$ were further increased to $10 \mathrm{wt} \%$, a sharp decrease of cell expansion degree was observed.

Biocompatibility of toughened ceramic has been studied mostly in terms of in vitro cytocompatibility, but fewer in vivo analysis has been conducted, which is a vital process before being considered for clinical applications. Petre et al. (2019) investigated the in vivo biocompatibility of both resorbable and nonresorbable PVA fiber-reinforced calcium phosphate cements. And these fibers were well dispered in the matrix without inducing inflammatory responses or other adverse reactions. Moreover, the inclusion of PVA fibers did not negatively affect the ingrowth of new bone into the PVA fiberreinforced cements. The in vivo test of Kucko et al. (2019) also showed that PVA fibers do not compromise the excellent osteocompatibility of calcium phosphate cements. Nevertheless, further in vivo studies should be performed to investigate the biocompatibility of various types of toughened ceramics in more detail.

Degradability is significant for biomaterials like bone substitutes, which determines the final repair effect of bioimplants; while biomaterials for other applications, such as dental restorations or artificial joint, require to be stable rather than degradable. Therefore, most degradability tests of toughened ceramic are conducted in bone substitute ceramic composites. Significantly influenced by mechanical properties of biomaterials, degradability is mostly tested by soaking materials in the simulated body fluid (SBF) (Xiang et al., 2007). Toughening strategies, especially second phase addition may change the degradation rate and degradability. Li et al. (2015) found that the addition of $\mathrm{ZnO}$ or $\mathrm{ZrO}_{2}$ decreased the degradation rate, and improved the degradability of wollastonite. Similarly, Feng et al. (2014) observed the degradation rate of calcium silicate ceramic scaffolds decreased with the increase of hydroxyapatite whisker content. Moreover, toughened bone substitute ceramic possesses the apatite-forming ability in SBF, and osteoblastlike cells spread well on the scaffolds and proliferated with increasing culture time (Feng et al., 2014; Mehrali et al., 2014; Li et al., 2015). However, soaking in the SBF tests only the in vitro bio-degradability, and in vivo degradability should also be increasingly studied in the future.

\subsection{Trade-Off Between Toughness and Strength, as Well as Esthetic and Function}

Toughness and strength are typically exclusive properties, which means the improvement of toughness usually comes with a decrease in strength (Launey and Ritchie, 2009). If the decrease of strength is within proper range, the toughening methods are still acceptable, because of the following reasons. On the one hand, the strength of most ceramic is high enough to satisfy clinical requirements. On the other hand, the best strength is not the highest but the strength that matches those of the human tissues. Therefore, toughening is a more essential issue than strengthening for ceramics of biomedical applications and receives extensive attentions. Toughening strategies from second phase addition, surface modification to manufacturing process improvement have been studied to solve this problem. Considering different clinical application scenarios, ceramics for biomedical applications could be classified as estheticdemanding and non-esthetic-demanding: dental restorations are the representatives of the former type of ceramic, in which esthetic sometimes is even paid more attention than toughness; while the latter, such as dental implants and artificial joints which could not be seen, mainly requires promising mechanical properties, especially toughness. What's more, studies concerning esthetic, including color and translucency, are still limited. Adding reinforcing fillers as second phase to ceramic matrix is one of the most widely used strategies, and even commercial ceramic products have been fabricated based on this strategy; in contrast, surface modification strategies gain less studies and applications. Toughening based on $\mathrm{ZrO}_{2}-$ $\mathrm{Al}_{2} \mathrm{O}_{3}$ system or mica glass ceramics (Gali and Kumar, 2019), and using ion-exchange (chemical methods) tends to preserve excellent esthetics, while adding colorful fillers like AgNPs (Fujieda et al., 2012) would affect ceramic color. For nonesthetic demanding applications, high toughness is the first consideration, which is fine achieved by fiber/whisker-shape (Aguilar-Elguézabal and Bocanegra-Bernal, 2013) or nanocarbon adding (Siddiqui et al., 2018).

\subsection{Other Challenges}

The $\mathrm{ZrO}_{2}-\mathrm{Al}_{2} \mathrm{O}_{3}$ system is well studied and used in clinic, such as dental restorations and implants, as well as femoral heads and hip joints. Although the addition of $\mathrm{Al}_{2} \mathrm{O}_{3}$ helps to improve the problem of low-temperature degradation (LTD) of $\mathrm{ZrO}_{2}$, it should still be paid enough attention during application, because most medical devices are applied in humid body environment which promotes degradation (Nguyen et al., 2009; Borchers et al., 2010). LTD refers to the t-to-m transformation of $\mathrm{ZrO}_{2}$ induced by hydrothermal aging in the humid environments, and with LTD, the energy barrier for t-to$\mathrm{m}$ transformation is decreased due to incorporation of water constituents into zirconia lattice (Guo, 2004). Non-metal materials, especially nanocarbon materials, show their potential as reinforcement fillers due to excellent mechanical properties. Nevertheless, the application of nanocarbon materials still faces some challenges. Firstly, it's difficult for nanocarbon to disperse in ceramic matrix due to its large specific surface area, surface energy, van der Waals forces caused by the intermolecular electrical dipole moment, and interactions between functional groups, as well as easy aggregation and entanglement properties (Liang et al., 2018). Secondly, the interface invasion between nanocarbon and ceramic is regarded unsuitable due to the differences in surface tension and density. Furthermore, it is difficult to determine the temperature during sintering, because nanocarbon can be destroyed at high temperatures when interface bonding is diminished. What's more, measurement of ceramic matrix composites with nanocarbon is not homogeneous, for the composites are extremely anisotropic (Liu et al., 2020). Therefore, combination of different types of second phase materials may be a possible approach to exert synergistic effect and, in the meantime, diminish their disadvantages. 
In addition to the type of second phase, the complex transition zone between ceramic matrix and reinforcement fillers, namely the interface, also play an important role on toughening, which is the basis of toughening mechanisms, such as pull-out and crack bridging. Proper interface strength is neither too weak nor too strong, so that the toughening mechanisms could dissipate energy during the loading process appropriately (Liu J et al., 2013; Ramirez et al., 2014; Ahmad et al., 2015).

De Aza et al. (2002) pointed out that the idea of a well-defined stress limit, toughness $\left(\mathrm{K}_{\mathrm{IC}}\right)$, must incorporate the concept of a threshold $\left(\mathrm{K}_{\mathrm{I} 0}\right)$ under which crack propagation does not occur. The $\mathrm{K}_{\mathrm{IC}}$ usually used only represents the resistance to fast fracture. However, ceramic materials are susceptible to slow crack propagation at $\mathrm{K}_{\mathrm{I}}$ values under $\mathrm{K}_{\mathrm{IC}}$, which is attributed to stress assisted corrosion at the crack tip, or any pre-existing defect in ceramic. The combined effect of high stresses at the crack tip and the presence of water or body fluid induce crack propagation in a subcritial manner (Chevalier et al., 1999). This slow crack propagation threshold may represent an intrinsic property of ceramic that gives information of its mechanical properties more realistic than the widely used toughenss, which represents only fast crack growth. The concept of slow crack propagation reminds us to pay attention to evaluations of mechanical properties, which may overestimate the behavior of ceramics.

\subsection{Future Outlook}

Microscopic building blocks, weak interfaces, and architecture are responsible for the extraordinary qualities of highly mineralized natural materials. Bio-inspired concepts could pave the way for new techniques to improve the toughness of brittle materials with enticing features but limited uses due to their brittleness (Wondraczek et al., 2011). These new materials show that bioinspired techniques can be used to achieve both strength and toughness, which are normally mutually exclusive qualities (Ritchie, 2011). Nature transforms brittleness into toughness through three "overarching features": (I) stiff and hard construction blocks are separated by (II) weaker interfaces, which are organized in (III) specialized architectures (Mirkhalaf et al., 2014). It may seem contradictory to make a material tougher by adding weak interfaces, but it appears to be a ubiquitous and powerful method in natural materials. Mirkhalaf et al. (2014) used three-dimensional laser engraving to create weak interfaces inside the bulk of glass and then infiltrating the interfaces with polyurethane. The crack is channeled towards toughening configurations by the weak interfaces, which obstructs its propagation. The technology produces a bioinspired glass that is 200 times tougher than non-engraved, "intact" glass (namely bulk glass, which was not engraved, but that is not devoid of the surface defects typical to glass exposed to air). Glass and ceramic are both brittle materials, therefore, above mentioned bio-inspired method could also be attempted in ceramics. These bio-inspired concepts have opened new pathways to improving the toughness of ceramics, and in the recent years, increasing numbers of synthetic composites inspired from biological materials have emerged (Munch et al., 2008; Espinosa et al., 2011). This is one of the development directions of the future, with still limited researches, which calls for more investigating efforts.

\section{CONCLUSION}

Ceramic encounters limitations during biomedical applications due to its brittleness. Various extrinsic toughening strategies have been proposed to deal with this problem, including adding reinforcing fillers as second phase, surface modification and manufacture processes optimization. Proper concentration of metal or/and non-metal components, with different shapes, could both be added in ceramic matrix to enhance toughness, which is the mainstream of ceramic toughening, especially in the biomedical area. Apart from traditional dispersed-filler composites, dual phase interpenetrating networks and bioinspired "block and mortar" architectures have also been developed to achieve better toughening effects. Surface coating, chemical and thermal toughening approaches could influence some depth of superficial layer to impede ceramic breakage, but each exhibit limitations. Furthermore, preparation of raw materials and forming methods of ceramic should be improved, as well. Underlying toughening mechanisms of these approaches include fine-grained toughening, stressinduced phase transformation toughening, microcrack toughening, crack deflection and bifurcation, and crack bridging and pull-out. In the future, effective combination of several toughening strategies and mechanisms should be the potential direction to extend the application scope of ceramic in biomedicine.

\section{AUTHOR CONTRIBUTIONS}

$\mathrm{RB}$ and $\mathrm{QS}$ wrote the original draft. RB, QS, YH and TY revised the manuscript. LP, YZ, LZ, WL, JD, ZZ reviewed the manuscript. YH, TY, and YW designed the work of review. All authors contributed to the article and approved the submitted version.

\section{FUNDING}

This work was funded by the National Key Research and Development Program of China (2020YFA0710401, 2021YFC2400403), the National Natural Science Foundation of China (51972005, U21A2055, 82101074, 51903003) and National Youth Top-notch Talent Support Program (QNBJ2019-3). 


\section{REFERENCES}

Aguilar-Elguézabal, A., and Bocanegra-Bernal, M. H. (2013). Alumina Toughened Zirconia Nanocomposite Incorporating Al2O3Whiskers. Int. J. Appl. Ceram. Technol. 10 (2), 215-223. doi:10.1111/j.1744-7402.2012.02759.x

Ahmad, I., Yazdani, B., and Zhu, Y. (2015). Recent Advances on Carbon Nanotubes and Graphene Reinforced Ceramics Nanocomposites. Nanomaterials 5 (1), 90-114. doi:10.3390/nano5010090

Akasaka, T., Watari, F., Sato, Y., and Tohji, K. (2006). Apatite Formation on Carbon Nanotubes. Mater. Sci. Eng. C 26 (4), 675-678. doi:10.1016/j.msec.2005.03.009

Al-Amleh, B., Neil Waddell, J., Lyons, K., and Swain, M. V. (2014). Influence of Veneering Porcelain Thickness and Cooling Rate on Residual Stresses in Zirconia Molar Crowns. Dental Mater. 30 (3), 271-280. doi:10.1016/j.dental. 2013.11.011

Allen, M. J., Tung, V. C., and Kaner, R. B. (2010). Honeycomb Carbon: a Review of Graphene. Chem. Rev. 110 (1), 132-145. doi:10.1021/cr900070d

Anstis, G. R., Chantikul, P., Lawn, B. R., and Marshall, D. B. (1981). A Critical Evaluation of Indentation Techniques for Measuring Fracture Toughness: I, Direct Crack Measurements. J. Am. Ceram. Soc. 64 (9), 533-538. doi:10.1111/j. 1151-2916.1981.tb10320.x

Asl, M. S., Nayebi, B., Ahmadi, Z., Zamharir, M. J., and Shokouhimehr, M. (2018). Effects of Carbon Additives on the Properties of ZrB2-Based Composites: A Review. Ceramics Int. 44 (7), 7334-7348. doi:10.1016/j.ceramint.2018.01.214

Bai, H., Xiu, H., Gao, J., Deng, H., Zhang, Q., Yang, M., et al. (2012). Tailoring Impact Toughness of Poly(1-lactide)/Poly ( $\varepsilon$-Caprolactone) (PLLA/PCL) Blends by Controlling Crystallization of PLLA Matrix. ACS Appl. Mater. Inter. 4 (2), 897-905. doi:10.1021/am201564f

Bartolomé, J. F., Smirnov, A., Kurland, H.-D., Grabow, J., and Müller, F. A. (2016). New ZrO2/Al2O3 Nanocomposite Fabricated from Hybrid Nanoparticles Prepared by CO2 Laser Co-vaporization. Sci. Rep. 6, 20589. doi:10.1038/srep20589

Bayne, S. C., Ferracane, J. L., Marshall, G. W., Marshall, S. J., and van Noort, R. (2019). The Evolution of Dental Materials over the Past Century: Silver and Gold to Tooth Color and beyond. J. Dent Res. 98 (3), 257-265. doi:10.1177/ 0022034518822808

Becher, P. F. (1991). Microstructural Design of Toughened Ceramics. J. Am. Ceram. Soc. 74 (2), 255-269. doi:10.1111/j.1151-2916.1991.tb06872.x

Becher, P. F. (1990). Recent Advances in Whisker-Reinforced Ceramics. Annu. Rev. Mater. Sci. 20, 179-195. doi:10.1146/annurev.ms.20.080190.001143

Benaqqa, C., Chevalier, J., Saädaoui, M., and Fantozzi, G. (2005). Slow Crack Growth Behaviour of Hydroxyapatite Ceramics. Biomaterials 26 (31), 6106-6112. doi:10.1016/j.biomaterials.2005.03.031

Borchers, L., Stiesch, M., Bach, F.-W., Buhl, J.-C., Hübsch, C., Kellner, T., et al. (2010). Influence of Hydrothermal and Mechanical Conditions on the Strength of Zirconia. Acta Biomater. 6 (12), 4547-4552. doi:10.1016/j.actbio.2010.07.025

Brostow, W., Hagg Lobland, H. E., and Khoja, S. (2015). Brittleness and Toughness of Polymers and Other Materials. Mater. Lett. 159, 478-480. doi:10.1016/j. matlet.2015.07.047

Carr, A. J., Robertsson, O., Graves, S., Price, A. J., Arden, N. K., Judge, A., et al. (2012). Knee Replacement. The Lancet 379 (9823), 1331-1340. doi:10.1016/ s0140-6736(11)60752-6

Carrington, J. L. (2005). Aging Bone and Cartilage: Cross-Cutting Issues. Biochem. Biophysical Res. Commun. 328 (3), 700-708. doi:10.1016/j.bbrc.2004.12.041

Cesar, P. F., Yoshimura, H. N., Miranda Júnior, W. G., and Okada, C. Y. (2005). Correlation between Fracture Toughness and Leucite Content in Dental Porcelains. J. Dentistry 33 (9), 721-729. doi:10.1016/j.jdent.2005.02.001

Chaim, R. (2008). Corrigendum to "Densification Mechanisms in Spark Plasma Sintering of Nanocrystalline Ceramics" [Mater. Sci. Eng. A 443 (2007) 25-32]. Mater. Sci. Eng. A 486 (1-2), 696. doi:10.1016/j.msea.2008.02.031

Chen, C. K. (2005). Statistical Simulation of Microcrack Toughening in Advanced Ceramics. J. Eur. Ceram. Soc. 25 (14), 3293-3299. doi:10.1016/j.jeurceramsoc. 2004.08.017

Cheng, Y., Hu, P., Zhou, S., Zhang, X., and Han, W. (2018). Using Macroporous Graphene Networks to Toughen ZrC-SiC Ceramic. J. Eur. Ceram. Soc. 38 (11), 3752-3758. doi:10.1016/j.jeurceramsoc.2018.04.037

Chevalier, J., and Gremillard, L. (2009). Ceramics for Medical Applications: A Picture for the Next 20 Years. J. Eur. Ceram. Soc. 29 (7), 1245-1255. doi:10. 1016/j.jeurceramsoc.2008.08.025
Chevalier, J., Olagnon, C., and Fantozzi, G. (1999). Subcritical Crack Propagation in 3Y-TZP Ceramics: Static and Cyclic Fatigue. J. Am. Ceram. Soc. 82 (11), 3129-3138.

Coldea, A., Swain, M. V., and Thiel, N. (2013). Mechanical Properties of PolymerInfiltrated-Ceramic-Network Materials. Dental Mater. 29 (4), 419-426. doi:10. 1016/j.dental.2013.01.002

Damani, R., Gstrein, R., and Danzer, R. (1996). Critical Notch-Root Radius Effect in SENB-S Fracture Toughness Testing. J. Eur. Ceram. Soc. 16 (7), 695-702. doi:10.1016/0955-2219(95)00197-2

De Aza, A. H., Chevalier, J., Fantozzi, G., Schehl, M., and Torrecillas, R. (2002). Crack Growth Resistance of Alumina, Zirconia and Zirconia Toughened Alumina Ceramics for Joint Prostheses. Biomaterials 23 (3), 937-945. doi:10.1016/s0142-9612(01)00206-x

Della Bona, A., Corazza, P. H., and Zhang, Y. (2014). Characterization of a Polymer-Infiltrated Ceramic-Network Material. Dental Mater. 30 (5), 564-569. doi:10.1016/j.dental.2014.02.019

Deubener, J., Allix, M., Davis, M. J., Duran, A., Höche, T., Honma, T., et al. (2018). Updated Definition of Glass-Ceramics. J. Non-Crystalline Sol. 501, 3-10. doi:10. 1016/j.jnoncrysol.2018.01.033

Donald, I. W. (1989). Methods for Improving the Mechanical Properties of Oxide Glasses. J. Mater. Sci. 24 (12), 4177-4208. doi:10.1007/BF00544488

Dong, Z., Jiang, C., Cheng, H., Zhao, Y., Shi, G., Jiang, L., et al. (2012). Facile Fabrication of Light, Flexible and Multifunctional Graphene Fibers. Adv. Mater. 24 (14), 1856-1861. doi:10.1002/adma.201200170

El Zhawi, H., Kaizer, M. R., Chughtai, A., Moraes, R. R., and Zhang, Y. (2016). Polymer Infiltrated Ceramic Network Structures for Resistance to Fatigue Fracture and Wear. Dental Mater. 32 (11), 1352-1361. doi:10.1016/j.dental. 2016.08.216

Entezari, A., Roohani-Esfahani, S.-I., Zhang, Z., Zreiqat, H., Dunstan, C. R., and Li, Q. (2016). Fracture Behaviors of Ceramic Tissue Scaffolds for Load Bearing Applications. Sci. Rep. 6, srep28816. doi:10.1038/srep28816

Espinosa, H. D., Juster, A. L., Latourte, F. J., Loh, O. Y., Gregoire, D., and Zavattieri, P. D. (2011). Tablet-level Origin of Toughening in Abalone Shells and Translation to Synthetic Composite Materials. Nat. Commun. 2, 1172. doi:10.1038/ncomms 1172

Evans, A. G., and Charles, E. A. (1976). Fracture Toughness Determinations by Indentation. J. Am. Ceram. Soc. 59 (7-8), 371-372. doi:10.1111/j.1151-2916. 1976.tb10991.x

Evans, A. G. (1990). Perspective on the Development of High-Toughness Ceramics. J. Am. Ceram. Soc. 73 (2), 187-206. doi:10.1111/j.1151-2916.1990. tb06493.x

Faber, K. T., and Evans, A. G. (1983). Crack Deflection Processes-I. Theory. Acta Metallurgica 31 (4), 565-576. doi:10.1016/0001-6160(83)90046-9

Faga, M. G., Vallée, A., Bellosi, A., Mazzocchi, M., Thinh, N. N., Martra, G., et al. (2012). Chemical Treatment on Alumina-Zirconia Composites Inducing Apatite Formation with Maintained Mechanical Properties. J. Eur. Ceram. Soc. 32 (10), 2113-2120. doi:10.1016/j.jeurceramsoc.2011.12.020

Falcao, E. H., and Wudl, F. (2007). Carbon Allotropes: beyond Graphite and diamond. J. Chem. Technol. Biotechnol. 82 (6), 524-531. doi:10.1002/jctb.1693

Fan, B.-W., Zhu, K.-Q., Shi, Q., Sun, T., Yuan, N.-Y., and Ding, J.-N. (2016). Effect of Glass Thickness on Temperature Gradient and Stress Distribution during Glass Tempering. J. Non-Crystalline Sol. 437, 72-79. doi:10.1016/j.jnoncrysol. 2016.01.008

Feng, P., Wei, P., Li, P., Gao, C., Shuai, C., and Peng, S. (2014). Calcium Silicate Ceramic Scaffolds Toughened with Hydroxyapatite Whiskers for Bone Tissue Engineering. Mater. Characterization 97, 47-56. doi:10.1016/j.matchar.2014. 08.017

Feng, X.-Q., Mai, Y.-W., and Qin, Q.-H. (2003). A Micromechanical Model for Interpenetrating Multiphase Composites. Comput. Mater. Sci. 28 (3-4), 486-493. doi:10.1016/j.commatsci.2003.06.005

Fillery, S. P., and Lange, F. F. (2007). Ion-Exchanged Glass Laminates that Exhibit a Threshold Strength. J. Am. Ceram. Soc. 90 (8), 2502-2509. doi:10.1111/j.15512916.2007.01749.x

Fischer, H., De Souza, R. A., Wätjen, A. M., Richter, S., Edelhoff, D., Mayer, J., et al. (2008). Chemical Strengthening of a Dental Lithium Disilicate Glass-Ceramic Material. J. Biomed. Mater. Res. 87A (3), 582-587. doi:10.1002/jbm.a.31798

French, R. H., Glass, S. J., Ohuchi, F. S., Xu, Y.-N., and Ching, W. Y. (1994). Experimental and Theoretical Determination of the Electronic Structure and 
Optical Properties of Three Phases ofZrO2. Phys. Rev. B 49 (8), 5133-5142. doi:10.1103/PhysRevB.49.5133

Fujieda, T., Uno, M., Ishigami, H., Kurachi, M., Wakamatsu, N., and Doi, Y. (2012). Addition of Platinum and Silver Nanoparticles to Toughen Dental Porcelain. Dent. Mater. J. 31 (5), 711-716. doi:10.4012/dmj.2012-044

Gali, S., Kumar, K. R., Murthy, B. V. S., and Basu, B. (2018). Zirconia Toughened Mica Glass Ceramics for Dental Restorations. Dental Mater. 34 (3), e36-e45. doi:10.1016/j.dental.2018.01.009

Gali, S., and Kumar, K. R. (2019). Zirconia Toughened Mica Glass Ceramics for Dental Restorations: Wear, thermal, Optical and Cytocompatibility Properties. Dental Mater. 35 (12), 1706-1717. doi:10.1016/j.dental.2019.08.112

Gao, C., Deng, Y., Feng, P., Mao, Z., Li, P., Yang, B., et al. (2014). Current Progress in Bioactive Ceramic Scaffolds for Bone Repair and Regeneration. Ijms 15 (3), 4714-4732. doi:10.3390/ijms15034714

Gao, C., Feng, P., Peng, S., and Shuai, C. (2017). Carbon Nanotube, Graphene and boron Nitride Nanotube Reinforced Bioactive Ceramics for Bone Repair. Acta Biomater. 61, 1-20. doi:10.1016/j.actbio.2017.05.020

Garvie, R. C., and Hannink, R. H. (1975). Ceramic Steel? Nature 258, 703-704. doi:10.1038/258703a0

Gil-Flores, L., Salvador, M. D., Penaranda-Foix, F. L., Dalmau, A., Fernández, A., and Borrell, A. (2020). Tribological and Wear Behaviour of Alumina Toughened Zirconia Nanocomposites Obtained by Pressureless Rapid Microwave Sintering. J. Mech. Behav. Biomed. Mater. 101, 103415. doi:10. 1016/j.jmbbm.2019.103415

Gommeringer, A., Nölle, L., Kern, F., and Gadow, R. (2019). Yttria Ceria Costabilized Zirconia Reinforced with Alumina and Strontium Hexaaluminate. Appl. Sci. 9 (4), 729. doi:10.3390/app9040729

Gregori, G., Burger, W., and Sergo, V. (1999). Piezo-spectroscopic Analysis of the Residual Stresses in Zirconia-Toughened Alumina Ceramics: the Influence of the Tetragonal-To-Monoclinic Transformation. Mater. Sci. Eng. a-Structural Mater. Properties Microstructure Process. 271 (1-2), 401-406. doi:10.1016/ S0921-5093(99)00383-4

Guo, X. (2004). Property Degradation of Tetragonal Zirconia Induced by LowTemperature Defect Reaction with Water Molecules. Chem. Mater. 16 (21), 3988-3994. doi:10.1021/cm040167h

Gy, R. (2008). Ion Exchange for Glass Strengthening. Mater. Sci. Eng. B 149 (2), 159-165. doi:10.1016/j.mseb.2007.11.029

Han, B., Zhao, C., Zhu, Z.-X., Chen, X., Han, Y., Hu, D., et al. (2017). TemperatureInsensitive Piezoelectric Performance in $\mathrm{Pb}(\mathrm{Zr} 0.52 \mathrm{Ti} 0.42 \mathrm{Sn} 0.02 \mathrm{Nb} 0.04) \mathrm{O} 3$ Ceramics Prepared by Spark Plasma Sintering. ACS Appl. Mater. Inter. 9 (39), 34078-34084. doi:10.1021/acsami.7b09825

Hannink, R. H. J., Kelly, P. M., and Muddle, B. C. (2000). Transformation Toughening in Zirconia-Containing Ceramics. J. Am. Ceram. Soc. 83 (3), 461-487.

Heuer, A. H., Claussen, N., Kriven, W. M., and Ruhle, M. (1982). Stability of Tetragonal Zro2 Particles in Ceramic Matrices. J. Am. Ceram. Soc. 65 (12), 642-650. doi:10.1111/j.1151-2916.1982.tb09946.x

Heuer, A. H. (1987). Transformation Toughening in Zro2-Containing Ceramics. J. Am. Ceram. Soc. 70 (10), 689-698. doi:10.1111/j.1151-2916.1987.tb04865.x

Himsolt, G., Knoch, H., Huebner, H., and Kleinlein, F. W. (1979). Mechanical Properties of Hot-Pressed Silicon Nitride with Different Grain Structures. J. Am. Ceram. Soc. 62 (1-2), 29-32. doi:10.1111/j.1151-2916.1979.tb18799.x

Hirsch, A. (2010). The Era of Carbon Allotropes. Nat. Mater 9 (11), 868-871. doi:10.1038/nmat2885

Horvitz, D., Gotman, I., Gutmanas, E. Y., and Claussen, N. (2002). In Situ processing of Dense Al2O3-Ti Aluminide Interpenetrating Phase Composites. J. Eur. Ceram. Soc. 22 (6), 947-954. doi:10.1016/S0955-2219(01)00396-X

Hunter, D. J., and Bierma-Zeinstra, S. (2019). Osteoarthritis. The Lancet 393 (10182), 1745-1759. doi:10.1016/s0140-6736(19)30417-9

Hutchinson, J. W. (1987). Crack Tip Shielding by Micro-cracking in Brittle Solids. Acta Metallurgica 35 (7), 1605-1619. doi:10.1016/0001-6160(87)90108-8

Hwang, D.-S., Kim, Y.-M., and Lee, C.-H. (2007). Alumina Femoral Head Fracture in Uncemented Total Hip Arthroplasty with a Ceramic sandwich Cup. The J. Arthroplasty 22 (3), 468-471. doi:10.1016/j.arth.2006.05.020

Jiang, L., Wang, Y., Mohagheghian, I., Li, X., Guo, X., Li, L., et al. (2017). Subcritical Crack Growth and Lifetime Prediction of Chemically Strengthened Aluminosilicate Glass. Mater. Des. 122, 128-135. doi:10.1016/j.matdes.2017. 03.020
Karthiselva, N. S., Murty, B. S., and Bakshi, S. R. (2018). Graphene Nanoplatelets Induce Crystallographic Texturing during Reactive Spark Plasma Sintering of Titanium Diboride. Carbon 133, 323-334. doi:10.1016/j.carbon.2018.03.052

Kelly, J. R., Nishimura, I., and Campbell, S. D. (1996). Ceramics in Dentistry: Historical Roots and Current Perspectives. The J. Prosthetic Dentistry 75 (1), 18-32. doi:10.1016/s0022-3913(96)90413-8

Kim, H.-A., Kim, S., Seo, Y. I., Choi, H. J., Seong, S.-C., Song, Y. W., et al. (2008). The Epidemiology of Total Knee Replacement in South Korea: National Registry Data. Rheumatology 47 (1), 88-91. doi:10.1093/rheumatology/kem308

Kohal, R.-J., Att, W., Bächle, M., and Butz, F. (2008). Ceramic Abutments and Ceramic Oral Implants. An Update. Periodontol 47, 224-243. doi:10.1111/j. 1600-0757.2007.00243.x

Kohorst, P., Borchers, L., Strempel, J., Stiesch, M., Hassel, T., Bach, F.-W., et al. (2012). Low-temperature Degradation of Different Zirconia Ceramics for Dental Applications. Acta Biomater. 8 (3), 1213-1220. doi:10.1016/j.actbio. 2011.11.016

Kong, N., Chen, A., Yan, W., and Zhang, H. (2019). Ceramic Implant Fracture: A Clinical Report. J. Prosthetic Dentistry 122 (5), 425-429. doi:10.1016/j.prosdent. 2019.01.011

Koo, K.-H., Ha, Y.-C., Kim, S.-Y., Yoon, K.-S., Min, B.-W., and Kim, S.-R. (2014). Revision of Ceramic Head Fracture after Third Generation Ceramic-OnCeramic Total Hip Arthroplasty. J. Arthroplasty 29 (1), 214-218. doi:10. 1016/j.arth.2013.04.007

Kucko, N. W., de Lacerda Schickert, S., Sobral Marques, T., Herber, R.-P., van den Beuken, J. J. J. P., Zuo, Y., et al. (2019). Tough and Osteocompatible Calcium Phosphate Cements Reinforced with Poly(vinyl Alcohol) Fibers. ACS Biomater. Sci. Eng. 5 (5), 2491-2505. doi:10.1021/acsbiomaterials.9b00226

Kucko, N. W., Petre, D.-G., de Ruiter, M., Herber, R.-P., and Leeuwenburgh, S. C. G. (2020). Micro- and Macromechanical Characterization of the Influence of Surface-Modification of Poly(vinyl Alcohol) Fibers on the Reinforcement of Calcium Phosphate Cements. J. Mech. Behav. Biomed. Mater. 109, 103776. doi:10.1016/j.jmbbm.2020.103776

Kuo, T. F., Chi, C. C., and Lin, I. N. (2001). Synthesis of Carbon Nanotubes by Laser Ablation of Graphites at Room Temperature. Jpn. J. Appl. Phys. 40, 7147-7150. doi:10.1143/jjap.40.7147

Lahiri, D., Singh, V., Keshri, A. K., Seal, S., and Agarwal, A. (2010). Carbon Nanotube Toughened Hydroxyapatite by Spark Plasma Sintering: Microstructural Evolution and Multiscale Tribological Properties. Carbon 48 (11), 3103-3120. doi:10.1016/j.carbon.2010.04.047

Lange, F. F. (1982). Transformation Toughening. J. Mater. Sci. 17 (1), 225-234. doi:10.1007/BF00809057

Launey, M. E., and Ritchie, R. O. (2009). On the Fracture Toughness of Advanced Materials. Adv. Mater. 21 (20), 2103-2110. doi:10.1002/adma.200803322

Lawn, B. R., Evans, A. G., and Marshall, D. B. (1980). Elastic/Plastic Indentation Damage in Ceramics: The Median/Radial Crack System. J. Am. Ceram. Soc. 63 (9-10), 574-581. doi:10.1111/j.1151-2916.1980.tb10768.x

Li, B. (2012). Effect of Toughening Mechanisms of Crack Bridging on Ceramic Materials. Amr 476-478, 1071-1074. doi:10.4028/www.scientific.net/AMR.476-478.1071

Li, D., Chen, Z. X., Zhang, Y. M., Li, X. C., Meng, M., He, L., et al. (2021). Improved Reliability of Mechanical Behavior for a thermal Tempered Lithium Disilicate Glass-Ceramic by Regulating the Cooling Rate. J. Mech. Behav. Biomed. Mater. 114, 104191. doi:10.1016/j.jmbbm.2020.104191

Li, H. C., Wang, D. G., and Chen, C. Z. (2015). Effect of Zinc Oxide and Zirconia on Structure, Degradability and In Vitro Bioactivity of Wollastonite. Ceramics Int. 41 (8), 10160-10169. doi:10.1016/j.ceramint.2015.04.117

Li, J., Zhang, X.-H., Cui, B.-C., Lin, Y.-H., Deng, X.-L., Li, M., et al. (2017). Mechanical Performance of Polymer-Infiltrated Zirconia Ceramics. J. Dentistry 58, 60-66. doi:10.1016/j.jdent.2017.01.008

Li, R. W. K., Chow, T. W., and Matinlinna, J. P. (2014). Ceramic Dental Biomaterials and CAD/CAM Technology: State of the Art. J. Prosthodontic Res. 58 (4), 208-216. doi:10.1016/j.jpor.2014.07.003

Li, X. C., Meng, M., Li, D., Wei, R., He, L., and Zhang, S. F. (2020). Strengthening and Toughening of a Multi-Component Lithium Disilicate Glass-Ceramic by Ion-Exchange. J. Eur. Ceram. Soc. 40 (13), 4635-4646. doi:10.1016/j. jeurceramsoc.2020.05.075

Liang, A., Jiang, X., Hong, X., Jiang, Y., Shao, Z., and Zhu, D. (2018). Recent Developments Concerning the Dispersion Methods and Mechanisms of Graphene. Coatings 8 (1), 33. doi:10.3390/coatings 8010033 
Liu, J., Yan, H., and Jiang, K. (2013). Mechanical Properties of Graphene PlateletReinforced Alumina Ceramic Composites. Ceramics Int. 39 (6), 6215-6221. doi:10.1016/j.ceramint.2013.01.041

Liu, J., Yan, H., Reece, M. J., and Jiang, K. (2012). Toughening of Zirconia/alumina Composites by the Addition of Graphene Platelets. J. Eur. Ceram. Soc. 32 (16), 4185-4193. doi:10.1016/j.jeurceramsoc.2012.07.007

Liu, Y., Huang, J., and Li, H. (2013). Synthesis of Hydroxyapatite-Reduced Graphite Oxide Nanocomposites for Biomedical Applications: Oriented Nucleation and Epitaxial Growth of Hydroxyapatite. J. Mater. Chem. B 1 (13), 1826-1834. doi:10.1039/c3tb00531c

Liu, Y., Jiang, X., Shi, J., Luo, Y., Tang, Y., Wu, Q., et al. (2020). Research on the Interface Properties and Strengthening-Toughening Mechanism of Nanocarbon-Toughened Ceramic Matrix Composites. Nanotechnology Rev. 9 (1), 190-208. doi:10.1515/ntrev-2020-0017

Liu, Y., Li, T., Ma, H., Zhai, D., Deng, C., Wang, J., et al. (2018). 3D-printed Scaffolds with Bioactive Elements-Induced Photothermal Effect for Bone Tumor Therapy. Acta Biomater. 73, 531-546. doi:10.1016/j.actbio.2018.04.014

Long, L., Zhang, F., Chen, L., Chen, L., and Chang, J. (2008). Preparation and Properties of $\beta$-CaSiO3/ZrO2 (3Y) Nanocomposites. J. Eur. Ceram. Soc. 28 (15), 2883-2887. doi:10.1016/j.jeurceramsoc.2008.05.006

Luo, X. P., Tian, J. M., Zhang, Y. L., and Wang, L. (2002). Strength and Fracture Toughness of MgO-Modified Glass Infiltrated Alumina for CAD/CAM. Dental Mater. 18 (3), 216-220. doi:10.1016/S0109-5641(01)00026-4

Ma, H., Feng, C., Chang, J., and Wu, C. (2018). 3D-printed Bioceramic Scaffolds: From Bone Tissue Engineering to Tumor Therapy. Acta Biomater. 79, 37-59. doi:10.1016/j.actbio.2018.08.026

Maccauro, G., Bianchino, G., Sangiorgi, S., Magnani, G., Marotta, D., Manicone, P. F., et al. (2009). Development of a New Zirconia-Toughened Alumina: Promising Mechanical Properties and Absence of In Vitro Carcinogenicity. Int. J. Immunopathol Pharmacol. 22 (3), 773-779. doi:10.1177/ 039463200902200323

Magnani, G., and Brillante, A. (2005). Effect of the Composition and Sintering Process on Mechanical Properties and Residual Stresses in Zirconia-Alumina Composites. J. Eur. Ceram. Soc. 25 (15), 3383-3392. doi:10.1016/j. jeurceramsoc.2004.09.025

Mainjot, A. K., Dupont, N. M., Oudkerk, J. C., Dewael, T. Y., and Sadoun, M. J. (2016). From Artisanal to CAD-CAM Blocks. J. Dent Res. 95 (5), 487-495. doi:10.1177/0022034516634286

Mehrali, M., Moghaddam, E., Seyed Shirazi, S. F., Baradaran, S., Mehrali, M., Latibari, S. T., et al. (2014). Mechanical and In Vitro Biological Performance of Graphene Nanoplatelets Reinforced Calcium Silicate Composite. PLoS One 9 (9), e106802. doi:10.1371/journal.pone.0106802

Mirkhalaf, M., Dastjerdi, A. K., and Barthelat, F. (2014). Overcoming the Brittleness of Glass through Bio-Inspiration and Micro-architecture. Nat. Commun. 5, 3166. doi:10.1038/ncomms4166

Miyazaki, T., Nakamura, T., Matsumura, H., Ban, S., and Kobayashi, T. (2013). Current Status of Zirconia Restoration. J. Prosthodontic Res. 57 (4), 236-261. doi:10.1016/j.jpor.2013.09.001

Morimoto, S., Rebello de Sampaio, F. B. W., Braga, M. M., Sesma, N., and Özcan, M. (2016). Survival Rate of Resin and Ceramic Inlays, Onlays, and Overlays. J. Dent Res. 95 (9), 985-994. doi:10.1177/0022034516652848

Moussa, H., Jiang, W., Alsheghri, A., Mansour, A., Hadad, A. E., Pan, H., et al. (2020). High Strength Brushite Bioceramics Obtained by Selective Regulation of crystal Growth with Chiral Biomolecules. Acta Biomater. 106, 351-359. doi:10. 1016/j.actbio.2020.01.047

Munch, E., Launey, M. E., Alsem, D. H., Saiz, E., Tomsia, A. P., and Ritchie, R. O. (2008). Tough, Bio-Inspired Hybrid Materials. Science 322 (5907), 1516-1520. doi:10.1126/science.1164865

Mussler, B., Swain, M. V., and Claussen, N. (1982). Dependence of Fracture Toughness of Alumina on Grain Size and Test Technique. J. Am. Ceram. Soc. 65 (11), 566-572. doi:10.1111/j.1151-2916.1982.tb10783.x

Nalla, R., Kinney, J. H., and Ritchie, R. O. (2003). Effect of Orientation on the In Vitro Fracture Toughness of Dentin: the Role of Toughening Mechanisms. Biomaterials 24 (22), 3955-3968. doi:10.1016/s01429612(03)00278-3

Naslain, R. (2004). Design, Preparation and Properties of Non-oxide CMCs for Application in Engines and Nuclear Reactors: an Overview. Composites Sci. Technol. 64 (2), 155-170. doi:10.1016/s0266-3538(03)00230-6
Nevarez-Rascon, A., Aguilar-Elguezabal, A., Orrantia, E., and Bocanegra-Bernal, M. H. (2009). On the Wide Range of Mechanical Properties of ZTA and ATZ Based Dental Ceramic Composites by Varying the $\mathrm{Al} 2 \mathrm{O} 3$ and $\mathrm{ZrO} 2$ Content. Int. J. Refractory Met. Hard Mater. 27 (6), 962-970. doi:10.1016/j.ijrmhm.2009. 06.001

Nguyen, H. Q., Tan, K. B., and Nicholls, J. I. (2009). Load Fatigue Performance of Implant-Ceramic Abutment Combinations. Int. J. Oral Maxillofac. Implants 24 (4), 636-646.

Nieto, A., Bisht, A., Lahiri, D., Zhang, C., and Agarwal, A. (2017). Graphene Reinforced Metal and Ceramic Matrix Composites: a Review. Int. Mater. Rev. 62 (5), 241-302. doi:10.1080/09506608.2016.1219481

Olshansky, S. J., Passaro, D. J., Hershow, R. C., Layden, J., Carnes, B. A., Brody, J., et al. (2005). A Potential Decline in Life Expectancy in the United States in the 21st century. N. Engl. J. Med. 352 (11), 1138-1145. doi:10.1056/NEJMsr043743

Pan, Y., Zuo, K., Yao, D., Yin, J., Xin, Y., Xia, Y., et al. (2016). The Improved Mechanical Properties of $\beta$-CaSiO 3 Bioceramics with Si 3 N 4 Addition. J. Mech. Behav. Biomed. Mater. 55, 120-126. doi:10.1016/j.jmbbm.2015.10.014

Patel, A., Pavlou, G., Mújica-Mota, R. E., and Toms, A. D. (2015). The Epidemiology of Revision Total Knee and Hip Arthroplasty in England and Wales. Bone Jt. J. 97-B (8), 1076-1081. doi:10.1302/0301-620X.97B8.35170

Petre, D.-G., Nadar, R., Tu, Y., Paknahad, A., Wilson, D. A., and Leeuwenburgh, S. C. G. (2019). Thermoresponsive Brushes Facilitate Effective Reinforcement of Calcium Phosphate Cements. ACS Appl. Mater. Inter. 11 (30), 26690-26703. doi:10.1021/acsami.9b08311

Pezzotti, G. (2019). Silicon Nitride: A Bioceramic with a Gift. ACS Appl. Mater. Inter. 11 (30), 26619-26636. doi:10.1021/acsami.9b07997

Piconi, C., and Maccauro, G. (1999). Zirconia as a Ceramic Biomaterial. Biomaterials 20 (1), 1-25. doi:10.1016/s0142-9612(98)00010-6

Pivec, R., Johnson, A. J., Mears, S. C., and Mont, M. A. (2012). Hip Arthroplasty. The Lancet 380 (9855), 1768-1777. doi:10.1016/s0140-6736(12)60607-2

Rahaman, M. N., Yao, A., Bal, B. S., Garino, J. P., and Ries, M. D. (2007). Ceramics for Prosthetic Hip and Knee Joint Replacement. J. Am. Ceram. Soc. 90 (7), 1965-1988. doi:10.1111/j.1551-2916.2007.01725.x

Ramirez, C., Miranzo, P., Belmonte, M., Osendi, M. I., Poza, P., Vega-Diaz, S. M., et al. (2014). Extraordinary Toughening Enhancement and Flexural Strength in $\mathrm{Si}_{3} \mathrm{~N}_{4}$ Composites Using Graphene Sheets. J. Eur. Ceram. Soc. 34 (2), 161-169. doi:10.1016/j.jeurceramsoc.2013.08.039

Raslan, A., Saenz Del Burgo, L., Ciriza, J., and Pedraz, J. L. (2020). Graphene Oxide and Reduced Graphene Oxide-Based Scaffolds in Regenerative Medicine. Int. J. Pharmaceutics 580, 119226. doi:10.1016/j.ijpharm.2020.119226

Rasmussen, S. T., McLaren, C. I., and O'Brien, W. J. (2004). The Effect of CesiumContaining Leucite Additions on the thermal and Mechanical Properties of Two Leucite-Based Porcelains. J. Biomed. Mater. Res. 69B (2), 195-204. doi:10. 1002/jbm.b.30008

Ritchie, R. O. (1988). Mechanisms of Fatigue Crack Propagation in Metals, Ceramics and Composites: Role of Crack Tip Shielding. Mater. Sci. Eng. A 103 (1), 15-28. doi:10.1016/0025-5416(88)90547-2

Ritchie, R. O. (2011). The Conflicts between Strength and Toughness. Nat. Mater 10 (11), 817-822. doi:10.1038/nmat3115

Ruiz Henao, P. A., Caneiro Queija, L., Mareque, S., Tasende Pereira, A., Liñares González, A., and Blanco Carrión, J. (2021). Titanium vs Ceramic Single Dental Implants in the Anterior Maxilla: A 12-month Randomized Clinical Trial. Clin. Oral Impl Res. 32 (8), 951-961. doi:10.1111/clr.13788

Saadaldin, S. A., and Rizkalla, A. S. (2014). Synthesis and Characterization of Wollastonite Glass-Ceramics for Dental Implant Applications. Dental Mater. 30 (3), 364-371. doi:10.1016/j.dental.2013.12.007

Santos, C. d., Coutinho, I. F., Amarante, J. E. V., Alves, M. F. R. P., Coutinho, M. M., and Moreira da Silva, C. R. (2021). Mechanical Properties of Ceramic Composites Based on $\mathrm{ZrO} 2 \mathrm{Co}$-stabilized by $\mathrm{Y} 2 \mathrm{O} 3-\mathrm{CeO} 2$ Reinforced with Al2O3 Platelets for Dental Implants. J. Mech. Behav. Biomed. Mater. 116, 104372. doi:10.1016/j.jmbbm.2021.104372

Sehaqui, H., Kochumalayil, J., Liu, A., Zimmermann, T., and Berglund, L. A. (2013). Multifunctional Nanoclay Hybrids of High Toughness, Thermal, and Barrier Performances. ACS Appl. Mater. Inter. 5 (15), 7613-7620. doi:10.1021/ am401928d

Serbena, F. C., Mathias, I., Foerster, C. E., and Zanotto, E. D. (2015). Crystallization Toughening of a Model Glass-Ceramic. Acta Materialia 86, 216-228. doi:10. 1016/j.actamat.2014.12.007 
Shirazi, F. S., Mehrali, M., Oshkour, A. A., Metselaar, H. S. C., Kadri, N. A., and Abu Osman, N. A. (2014). Mechanical and Physical Properties of Calcium Silicate/alumina Composite for Biomedical Engineering Applications. J. Mech. Behav. Biomed. Mater. 30, 168-175. doi:10.1016/j.jmbbm.2013. 10.024

Shuai, C., Zhou, J., Gao, D., Gao, C., Feng, P., and Peng, S. (2016). Functionalization of Calcium Sulfate/Bioglass Scaffolds with Zinc Oxide Whisker. Molecules 21 (3), 378. doi:10.3390/molecules21030378

Siddiqui, H., Pickering, K., and Mucalo, M. (2018). A Review on the Use of Hydroxyapatite-Carbonaceous Structure Composites in Bone Replacement Materials for Strengthening Purposes. Materials 11 (10), 1813. doi:10.3390/ ma11101813

Spitznagel, F. A., Boldt, J., and Gierthmuehlen, P. C. (2018). CAD/CAM Ceramic Restorative Materials for Natural Teeth. J. Dent Res. 97 (10), 1082-1091. doi:10. 1177/0022034518779759

Swain, M. V., Coldea, A., Bilkhair, A., and Guess, P. C. (2016). Interpenetrating Network Ceramic-Resin Composite Dental Restorative Materials. Dental Mater. 32 (1), 34-42. doi:10.1016/j.dental.2015.09.009

Swain, S. K., Gotman, I., Unger, R., Kirkpatrick, C. J., and Gutmanas, E. Y. (2016). Microstructure, Mechanical Characteristics and Cell Compatibility of $\beta$-tricalcium Phosphate Reinforced with Biodegradable Fe-Mg Metal Phase. J. Mech. Behav. Biomed. Mater. 53, 434-444. doi:10.1016/j.jmbbm.2015. 09.002

Torán, M. M., Cuenca, J., Martinez, Á. A., Herrera, A., and Thomas, J. V. (2006). Fracture of a Ceramic Femoral Head after Ceramic-On-Ceramic Total Hip Arthroplasty. J. Arthroplasty 21 (7), 1072-1073. doi:10.1016/j.arth.2005. 03.045

Uno, M., Kurachi, M., Wakamatsu, N., and Doi, Y. (2013). Effects of Adding Silver Nanoparticles on the Toughening of Dental Porcelain. J. Prosthetic Dentistry 109 (4), 241-247. doi:10.1016/s0022-3913(13)60052-9

Uno, S., Okada, M., Taketa, H., Torii, Y., and Matsumoto, T. (2020). Toughening of Highly Translucent Zirconia by Monoclinic ZrO2 and SiO2 Particle Coating. Dent. Mater. J. 39 (2), 295-301. doi:10.4012/dmj.2018-415

Wang, A., Hu, P., Zhang, X., Han, W., Chen, G., and Han, J. (2017). Accurate Measurement of Fracture Toughness in Structural Ceramics. J. Eur. Ceram. Soc. 37 (13), 4207-4212. doi:10.1016/j.jeurceramsoc.2017.05.027

Wang, J., and Stevens, R. (1989). Zirconia-Toughened Alumina (ZTA) Ceramics. J. Mater. Sci. 24 (10), 3421-3440. doi:10.1007/BF02385721
Wondraczek, L., Mauro, J. C., Eckert, J., Kühn, U., Horbach, J., Deubener, J., et al. (2011). Towards Ultrastrong Glasses. Adv. Mater. 23 (39), 4578-4586. doi:10. 1002/adma.201102795

Xiang, Q., Liu, Y., Sheng, X., and Dan, X. (2007). Preparation of Mica-Based GlassCeramics with Needle-like Fluorapatite. Dental Mater. 23 (2), 251-258. doi:10. 1016/j.dental.2006.10.008

Zhang, C., Jiang, Z., Zhao, L., Liu, W., Si, P., and Lan, J. (2020). Synthesis and Characterization of Multilayer Graphene Oxide on Yttria-Zirconia Ceramics for Dental Implant. J. Mater. Res. 35 (18), 2466-2477. doi:10.1557/jmr.2020.199

Zhang, J., Huang, D., Liu, S., Dong, X., Li, Y., Zhang, H., et al. (2019). Zirconia Toughened Hydroxyapatite Biocomposite Formed by a DLP 3D Printing Process for Potential Bone Tissue Engineering. Mater. Sci. Eng. C 105, 110054. doi:10.1016/j.msec.2019.110054

Zitzmann, N. U., Hagmann, E., and Weiger, R. (2007). What Is the Prevalence of Various Types of Prosthetic Dental Restorations in Europe? Clin. Oral Implants Res. 18, 20-33. doi:10.1111/j.1600-0501.2007.01435.x

Zou, H., Zhang, Y., Liu, L., Shi, L., and Li, W. (2018). The Toughening Mechanism and Mechanical Properties of Graphene-Reinforced Zirconia Ceramics by Microwave Sintering. Adv. Appl. Ceramics 117 (7), 420-426. doi:10.1080/ 17436753.2018 .1477566

Conflict of Interest: The authors declare that the research was conducted in the absence of any commercial or financial relationships that could be construed as a potential conflict of interest.

Publisher's Note: All claims expressed in this article are solely those of the authors and do not necessarily represent those of their affiliated organizations, or those of the publisher, the editors and the reviewers. Any product that may be evaluated in this article, or claim that may be made by its manufacturer, is not guaranteed or endorsed by the publisher.

Copyright (c) 2022 Bai, Sun, He, Peng, Zhang, Zhang, Lu, Deng, Zhuang, Yu and Wei. This is an open-access article distributed under the terms of the Creative Commons Attribution License (CC BY). The use, distribution or reproduction in other forums is permitted, provided the original author(s) and the copyright owner(s) are credited and that the original publication in this journal is cited, in accordance with accepted academic practice. No use, distribution or reproduction is permitted which does not comply with these terms. 


\section{GLOSSARY}

$\mathrm{Al}_{2} \mathrm{O}_{3}$ alumina

AgNPs silver nanoparticles

$\boldsymbol{\beta}$-TCP beta-tricalcium phosphate

BPO benzoyl peroxide

Bis-GMA Bisphenol A glycidyl dimethacrylate

$\mathrm{Cs}_{2} \mathrm{O}$ cesium oxide

$(\mathbf{C e}, \mathbf{Y})-\mathbf{T Z P}$ cerium oxide $\left(\mathrm{CeO}_{2}\right)$ and yttrium oxide $\left(\mathrm{Y}_{2} \mathrm{O}_{3}\right)$ stabilized zirconia $\left(\mathrm{ZrO}_{2}\right)$

$\mathrm{CaSiO}_{3}$ calcium silicate

$\mathrm{CaSO}_{4}$ calcium sulfate

CNT carbon nanotube

CPCs calcium phosphate cements

GNP graphene nanoplatelets

GO graphene oxide

GPL graphene platelet

HA hydroxyapatite

HIP hot isostatic pressing

IF indentation fracture method

$\mathbf{K}_{\mathbf{l c}}$ fracture toughness

L-(+)-Tar homochiral L-(+)-tartaric acid
NS Noritake Super Porcelain AAA (Noritake Dental Supply Co., Nagoya, Japan)

PtNPs platinum nanoparticles

PVA poly (vinyl alcohol)

PBS phosphate-buffered saline solution

PNIPAM poly(N-isopropylacrylamide)

PICN polymer infiltrated ceramic network

SPS spark plasma sintering

SA6 strontium hexaaluminate

SLS selective laser sintering

SENB single-edge notched beam

$\mathrm{Si}_{3} \mathrm{~N}_{4}$ silicon nitride

SEVNB single-edge V-notched beam

SEPB single-edge precracked beam

MgO magnesium oxide

TEGDMA Tri(ethyleneglycol) dimethacrylate

WOF work of fracture

3Y-TZP 3 mol\% yttria stabilized zirconia

1 Y6Ce-TZP 1 mol\% $\mathrm{Y}_{2} \mathrm{O}_{3}+6$ mol\% $\mathrm{CeO}_{2}$ stabilized $\mathrm{ZrO}_{2}$

ZnOw zinc oxide whisker

ZTA zirconia-toughened alumina

$\mathrm{ZrO}_{2}$ zirconia 